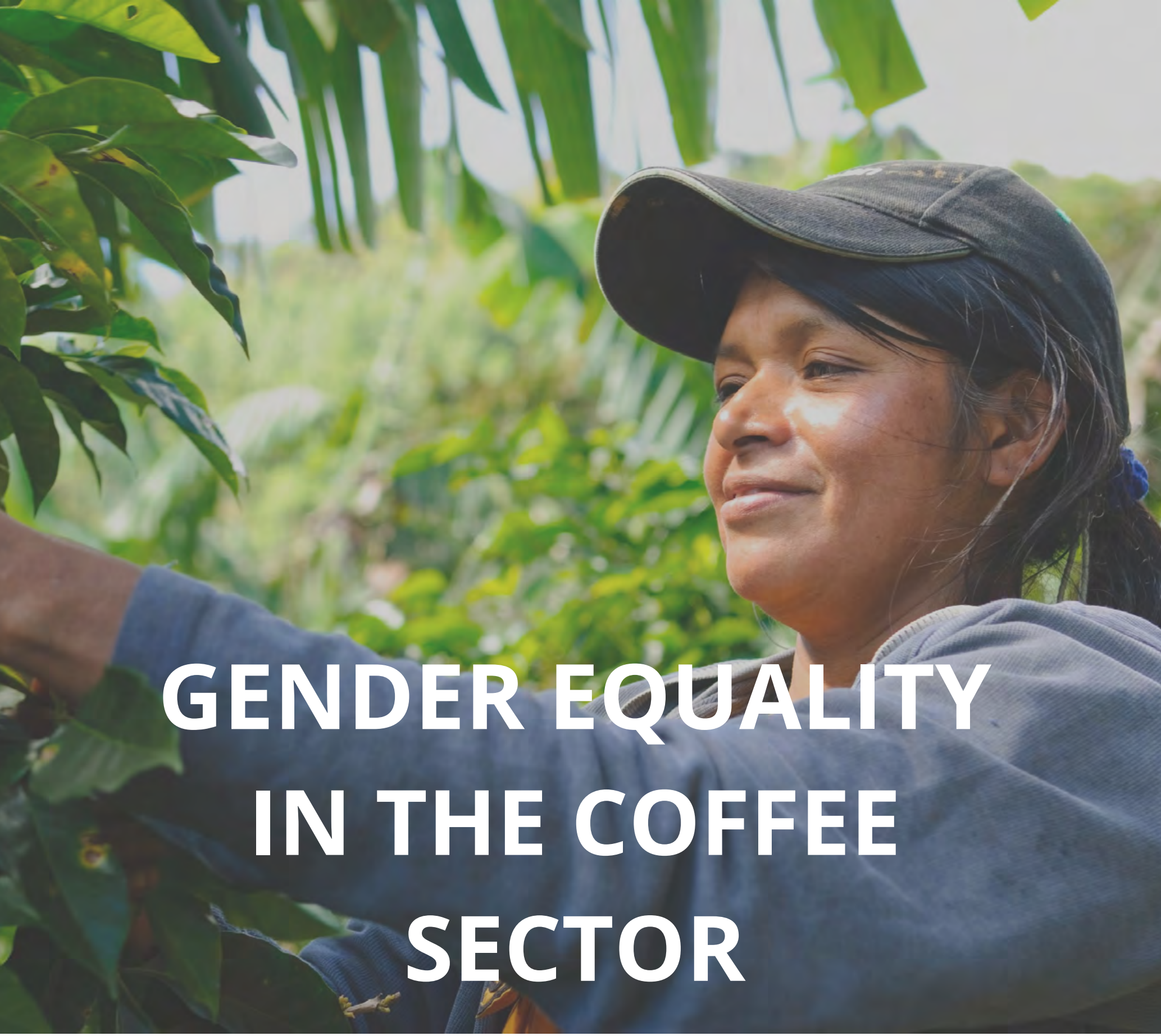




\section{About the International Coffee Organization}

The International Coffee Organization (ICO) is a multilateral organization supporting exporting and importing countries to improve the sustainability of the coffee sector. It provides a high-level forum for all public and private stakeholders in the sector; official statistics on coffee production, trade and consumption; and support for the development and funding of technical cooperation projects and public-private partnerships.

\section{International Coffee Organization}

222 Gray's Inn Road

London WC1X 8HB

United Kingdom

wWw.ico.org

\section{Acknowledgements}

We gratefully acknowledge the authors of all resources used to compile this study.

We give special thanks to Nestlé Nespresso, Taylors of Harrogate, Technoserve, Rainforest Alliance and UTZ, and UN Women for contributing best practice case studies.

This work is a product of the staff of the International Coffee Organization with external contributions. The findings, interpretations, and conclusions expressed in this work do not necessarily reflect the views of the International Coffee Council, or the governments they represent. Nothing herein shall constitute or be considered to be a limitation upon or waiver of the privileges and immunities of the International Coffee Organization all of which are specifically reserved.

Copyright $\odot 2018$ International Coffee Organization.

The material in this work is subject to copyright. Because the International Coffee Organization encourages dissemination of its knowledge, this work may be reproduced, in whole or in part, for noncommercial purposes as long as full attribution to this work is given. 


\section{Summary}

Women contribute significantly to the global coffee sector. Between $20 \%$ and $30 \%$ of coffee farms are female-operated and up to $70 \%$ of labour in coffee production is provided by women, depending on the region. However, the empirical evidence presented in this report shows that women have systematically lower access to resources, such as land, credit and information, than men. This often results in a measurable gender gap in economic outcomes, including yields, productivity and farm income. The gains from closing the gender gap are significant and there is a role for both the public and the private sectors, as well as consumers, in fostering empowerment and achieving gender equality.

This report discusses how gender-sensitive and evidence-based public policies, services and programmes, as well as sustainable supply chain policies, can reach, benefit and empower women. The resulting enhanced access to human and social capital, productive assets as well as finance and skills would enable women to produce more efficiently, achieving higher yields and farm profits. Improving women's resilience to economic shocks, such as volatile coffee prices, and building adaptive capacity to climate change also fosters long-term sustainability of rural livelihoods and coffee supply. Hence, empowerment of women involved in coffee production - as farm operators, family labour, or workers - directly contributes to achieving the Sustainable Development Goal of gender equality. Family members and rural communities will benefit from well documented positive spillovers in various dimensions of economic and social development such as food security, health and education.

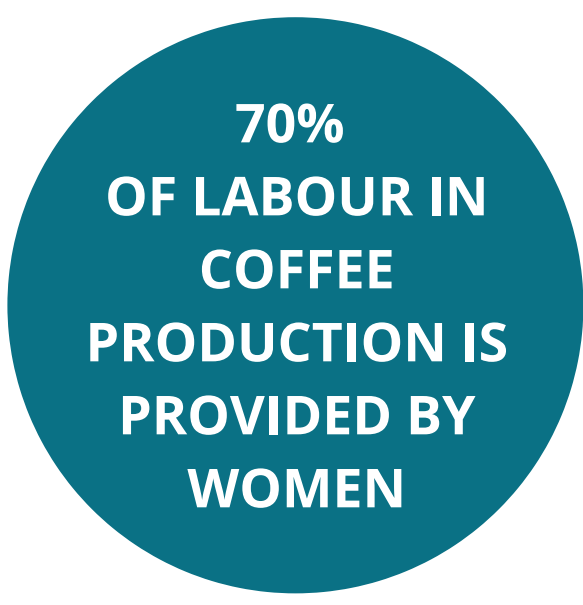




\section{CONTENTS}

1. Introduction 3

2. Women's empowerment, gender equality and the Sustainable Development Agenda 5

3. The gender gap in coffee production

3.1 Data availability, empirical strategy and scope of research 7

3.1 The role of women in coffee production 8

3.3 Gender gap in coffee production 10

3.4 The cost of disempowerment 14

4. Gender gap in accessing resources

4.1 Land and productive resources 16

4.2 Labour 17

4.3 Education 19

4.4 Extension and training programmes 20

4.5 Input use 22

4.6 Financial services 23

4.7 Social capital 24

5. Closing the gender gap

5.1 Empowerment, productivity gains, resilience and wider economic benefits 26

5.2 Closing the gap - a role for the public and private sectors 28

5.3 Land certification and property rights 30

5.4 Extension 30

5.5 Financial literacy and access to finance 31

5.6 Voluntary sustainability standards 32

5.7 Information and communication technology 34

5.8 Complementarities 34

6. Conclusion and next steps 35 


\section{INTRODUCION}

Coffee plays an important role in the economy of many tropical countries by providing livelihoods for an estimated 25 million rural households. The performance of the sector could be enhanced by strengthening the women who represent a crucial resource along the entire coffee value chain through their role as farmers, labourers or entrepreneurs but face severe constraints in accessing production factors.

Compared to men, female farm operators often have less access to land, inputs, finance and knowledge. Within rural households, women often have limited say in decision making, are constrained in their access to public services, such as training and extension programmes, and lack control over income derived from agricultural production as well as investment decisions. This differential in access to resources and empowerment translates into a gender gap in agronomic and economic outcomes, such as yields, revenues from crop sales and household welfare (FAO, 2011).

Fostering the empowerment of women in the coffee sector contributes to closing the gender gap and achieving gender equality, a global priority and one of the seventeen goals under the 2030 Agenda for Sustainable Development[1] adopted by the United Nations (UN).

Furthermore, strengthening the role of women supports broad-based development through improved livelihoods and rural incomes, with wider benefits in terms of household welfare, ranging from improved nutritional status to educational attainment of dependents. Increasing female farmers' productivity and resilience to the impact of climate change can also make a crucial contribution in meeting the future demand for coffee worldwide. 
This report aims at supporting policy makers, development institutions and coffee sector stakeholders by:

(i) Contributing to the understanding of the gender gap and its determinants.

(ii) Identifying approaches of the public and private sectors with the aim of closing the gender gap and meeting the SDGs.

(iii) Proposing ways as to how the ICO can actively promote gender equality in the coffee sector, in particular among its Member countries, by raising awareness among stakeholders and facilitating interventions through public-private partnerships.

Women contribute to the coffee sector at all levels of the global coffee value chain from farm to cup. This analysis focuses on the farm level, adding empirical evidence on women's role at origin. While beyond the scope of this report, the need for more research to assess gender equality in the trading, roasting and retailing stages of the coffee value chain is acknowledged. The remainder of the report is organized as follows: Chapter 2 discusses the link between gender equality and broad-based development in ICO Member countries; Chapter 3 presents empirical evidence on the role of women in the coffee sector, the gender gap and its social and economic impact; Chapter 4 identifies the main determinants of the gender gap; Chapter 5 examines the wider social and economic benefits of closing the gender gap and approaches taken by the public and private sectors. The report closes with a call for action.

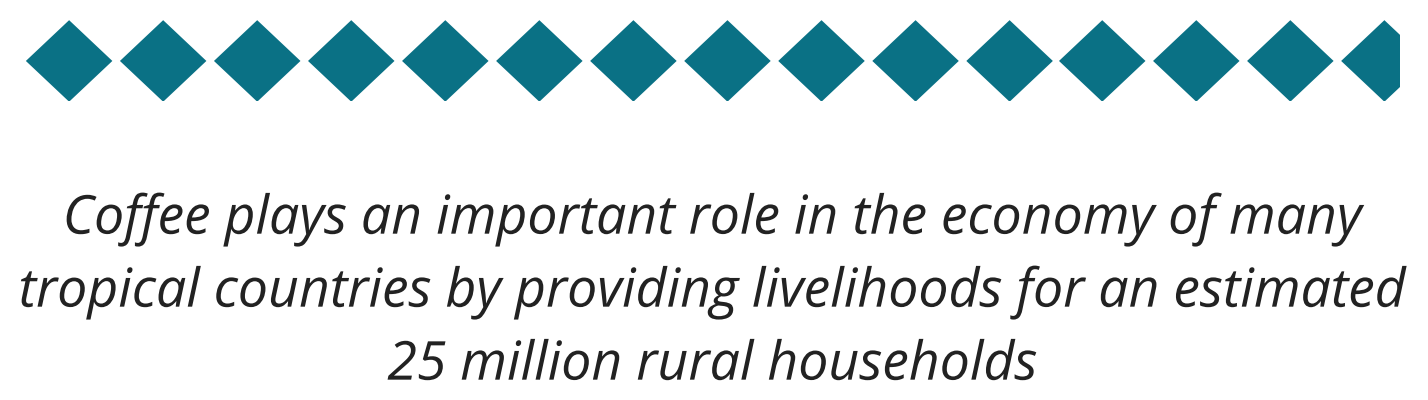




\section{WOMEN'S EMPOWERMENT, GENDER EQUALITY AND THE SUSTAINABLE DEVELOPMENT AGENDA}

Women's empowerment is a key objective of development policy (Alkire et al. 2012). Women's full participation in public, economic and political life is recognized as a necessary condition for gender equity and justice, as well as a driver of broad-based development and economic growth (Klasen, 2013).

The link between reduced inequality, improved economic performance and living conditions has been widely documented. Gender equality and human development are positively correlated and most research concludes that, while the causality could run in both directions, reduced inequalities promote economic growth (World Bank, 2012). Harnessing gender equality to spur economic growth is paramount for ICO exporting Members that rank low in development metrics, with 18 out of the 44 exporting Members of the ICO currently falling in the category of Least Developed Countries (LDCs) [2].

Figure 1 illustrates the instrumental argument for gender equality in ICO exporting Member countries using two commonly employed measures of the UN Human Development Index family: the Gender Inequality Index (GII), which reflects gender-based disadvantage in three dimensions - reproductive health, empowerment and the labour market and which ranges from zero, where women and men fare equally, to one, where one gender fares as poorly as possible in all measured dimensions; and the Human Development Index (HDI), which is a summary measure of achievements in three key dimensions of human development: a long and healthy life, access to knowledge and a decent standard of living. The cutoff points of the HDI for grouping countries that are very high human development 0.800 and above, high human development 0.700-0.79; medium human development 0.550-0.699; and low human development below 0.550 . 
Coffee-exporting countries featuring more severe levels of inequality, as indicated by a higher GII score, record lower scores in the UN Human Development Index. Hence, gender inequality imposes societal costs in foregone growth and economic performance. These results illustrate socio-economic patterns at the aggregate level of national economies and are likely to be indicative for the agricultural as well as the coffee sector. Nevertheless, a deeper understanding of the state of women's empowerment as well as equal opportunities in the coffee sector is required. In the next chapter, empirical evidence is provided to contribute to the understanding of inequalities in the agricultural and coffee sector and their impact on economic outcomes and the standard of living of women.

Figure 1: Gender inequality and development in ICO exporting Member countries are negatively correlated

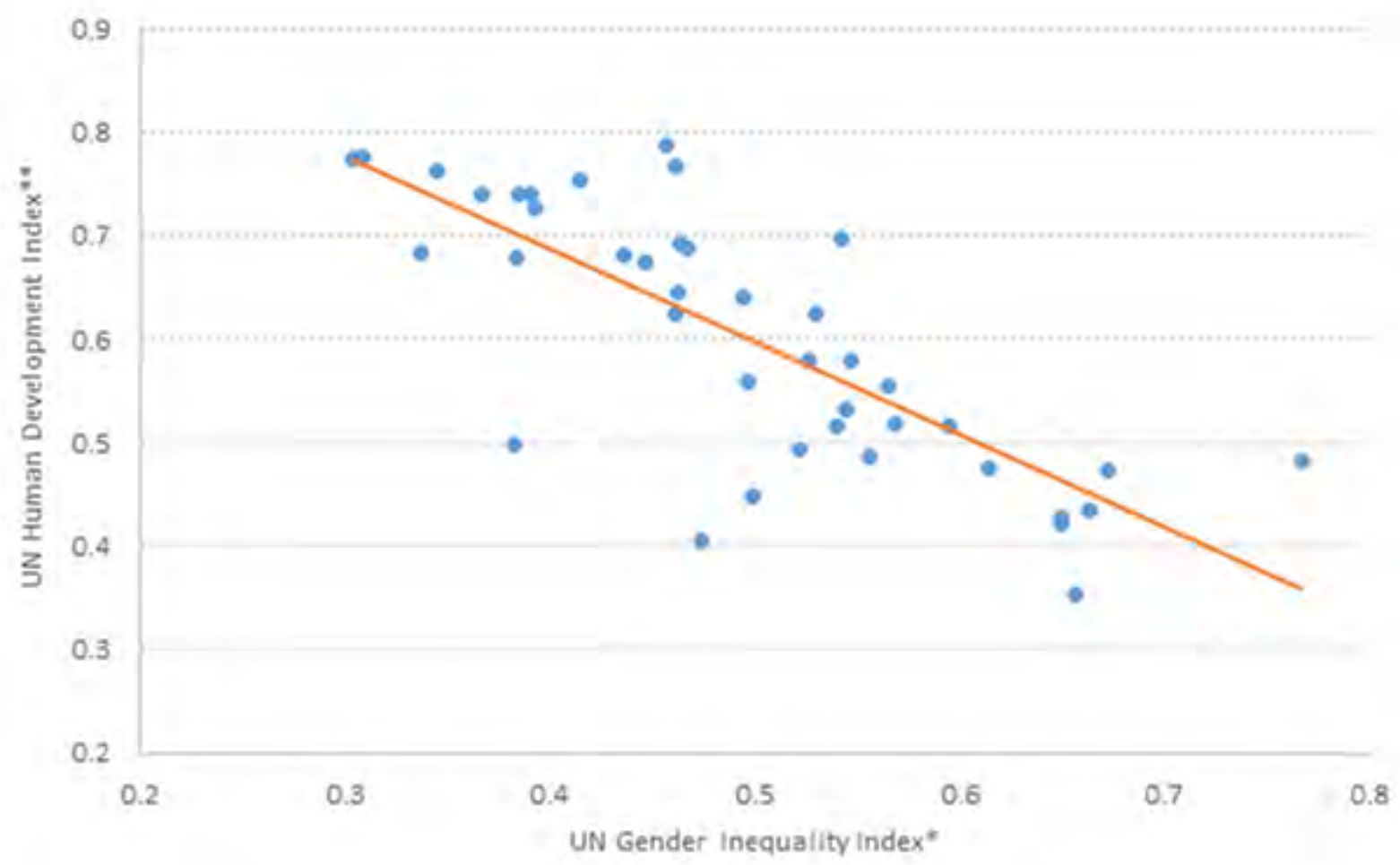

* The Gender Inequality Index (GII) reflects gender-based disadvantage in three dimensions-reproductive health, empowerment and the labour market. It shows the loss in potential human development due to inequality between female and male achievements in these dimensions

** The Human Development Index (HDI) is a summary measure of achievements in three key dimensions of human development: a long and healthy life, access to knowledge and a decent standard of living.

Source: UNDP 


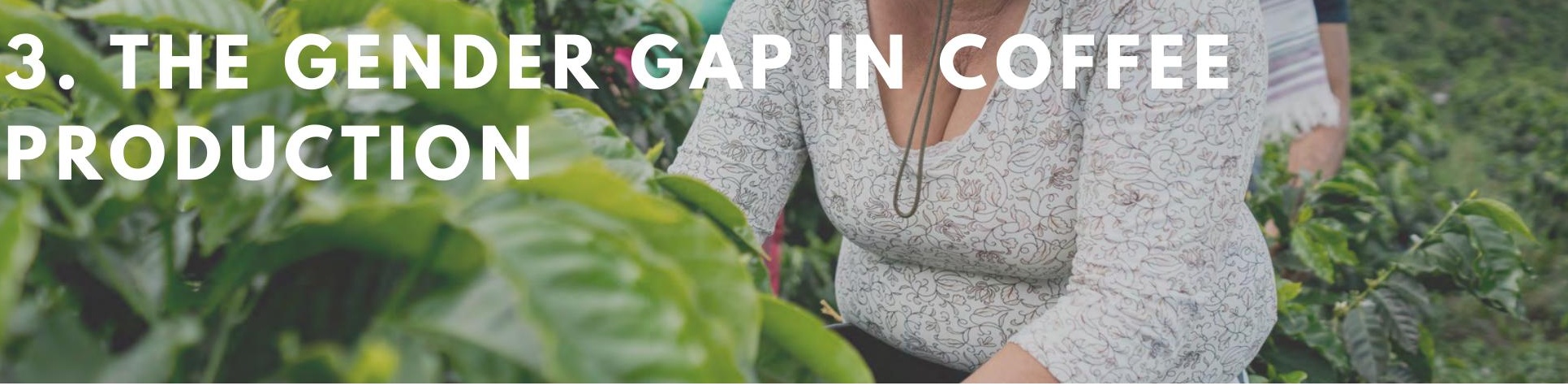

\subsection{Data availability, empirical strategy and scope of research}

Over the past two decades significant work has been undertaken to collect and analyse data in order to understand the contribution of women to global agricultural production, while identifying factors preventing female farmers from reaching their full economic potential. However, despite an increasing number of studies that map the gender gap across agricultural sectors, evidence remains patchy with varying levels of coverage of regions and sub-sectors (FAO, 2011; Doss, 2014).

For the following analysis we rely on a comprehensive review of empirical evidence from academic research and research reports of international organizations. The studies considered for this report usually involved collection of farm-level data. Depending on the sampling frame employed, the underlying datasets comprise information on several hundred households. The samples contain a sufficient number of observations for male and female headed households to draw inferences with high statistical significance. However, given that most studies are limited to one or several coffee-producing regions in a given country, the findings of each individual work, while internally consistent, may not be easily extrapolated to other countries or valid for the global coffee sector as a whole.

This report adds to the available empirical evidence by analysing World Bank census data from the Living Standards Measurement Study (LSMS). Under this programme micro-level data from nationally representative samples of individual households are being collected at regular intervals. For a number of countries in Africa the core LSMS survey is expanded by the Integrated Survey on Agriculture (ISA) to enable detailed information on farming activities of rural households to be gathered. Among the locations in which the LSMS-ISA was implemented, there are coffee-exporting countries, such as Ethiopia, Tanzania and Uganda [3]. 
Overall the cumulative empirical evidence compiled in this report both from existing studies and the analysis of World Bank census allows patterns and broad trends to be inferred. However, caution is still warranted so as not to generalize the conclusions on the state of women's empowerment and gender equality in the coffee sector, given the coverage is far from perfect, with a better representation of Africa (especially East Africa) than other continents (with Asia being particularly under-represented).

Gender analysis using micro-level data often distinguishes between male- and femaleheaded households. In the social context of rural areas women may head a household in case a principal male is missing, either temporarily due to internal or international migration or permanently due to divorce from or death of the male partner. Focusing exclusively on these female-headed households, which make up 5-30\% of rural households depending on location, results in overlooking the importance of understanding the relative position of women in male-headed households (Deere, Avarado and Twyman, 2012). In some regions, e.g. West Africa, there is shared responsibility for farming land, with men and women managing different plots (Croppenstedt, 2013). This intra-household distribution of task and decision making in agriculture poses a challenge to data collection and research, as household surveys often do not provide a detailed breakdown of information by gender.

In this report gender differences are analysed both at the level of male- and female-headed households and within male-headed households wherever sufficiently detailed data was available. Finally, the contribution of women to the coffee sector at all levels of the global coffee value chain is acknowledged. However, this report focuses on the role of women as coffee growers at farm level.

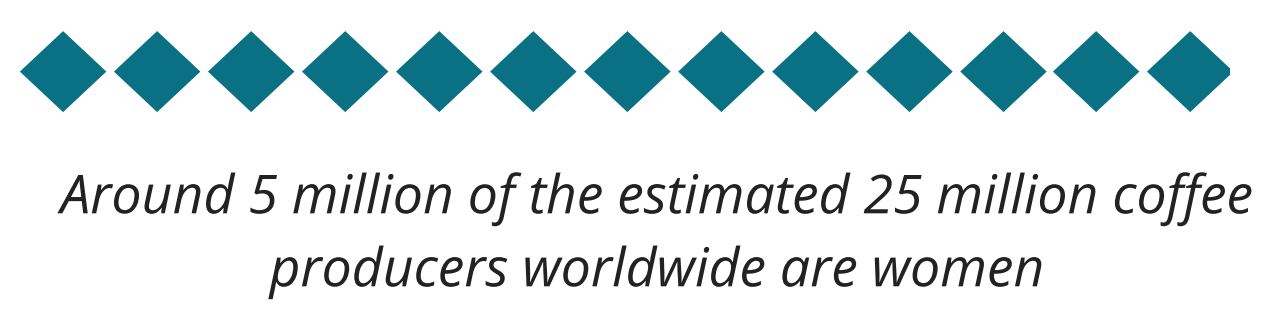

\subsection{The role of women in coffee production}

One of the first attempts to assess the role of women in coffee production at a global level was made by the International Trade Center. In their study, the share of labour in coffee production provided by women was estimated at 70\% (ITC, 2008). This includes female selfemployed farm operators, providers of paid and unpaid labour on family farms, and agricultural workers. Depending on the region significant variations in female labour contribution in coffee production can be found, reaching up to $90 \%$ in field work and up to $80 \%$ in harvesting activities [4]. Between $20 \%$ and $30 \%$ of coffee farms are operated by women. Hence, around 5 million of the estimated 25 million coffee producers worldwide are women. Table 1 contains the estimates from the ITC report as well as findings of other empirical studies carried out since. 
For the African continent, analysis of World Bank census data for Ethiopia, Uganda and Tanzania indicates that between $19 \%$ and $28 \%$ of coffee-producing households are headed by women depending on the country. Meemken and Qaim (2018) found that, in a representative sample from two regions in Uganda, $23 \%$ of coffee farming households were headed by women. In neighbouring Kenya, two cooperatives surveyed by Dijkdrenth (2015) had $29 \%$ and $34 \%$ female members, respectively.

Systematic evidence for Latin America and Asia is more limited. A study by Lyon et al. (2010) found that in Mexico and Central America the share of women registered Fairtradeorganic farm operators increased from 20\% to 35\% between 1997 and 2006. According to estimates of the International Women's Coffee Alliance (IWCA), a not-for-profit-

organization, between $19 \%$ and $34 \%$ total coffee producers in Central America are women. For Asia, a baseline study carried out by the International Finance Corporation (IFC) found that women provide up to $80 \%$ of labour on coffee farms in Northern Sumatra, Indonesia, and about $50 \%$ in Lam Dong, Vietnam, playing a key role in coffee cultivation, processing and marketing (IFC, 2018).

These findings are broadly in line with a comprehensive report of the Food and Agriculture Organization (FAO), according to which approximately $43 \%$ of the global rural labour force in agriculture is provided by women. Female household heads and farm operators make up on average $15 \%$ of agricultural land holders in Sub-Saharan Africa and well over $\mathbf{2 5 \%}$ in Latin America, while the share in Asia is significantly lower at less than $\mathbf{5 \%}$ (FAO, 2011).

Table 1: Female participation in the coffee sector compared to the agricultural sector

\begin{tabular}{|c|c|c|c|}
\hline $\begin{array}{c}\text { Share of } \\
\text { labour force }\end{array}$ & $\begin{array}{c}\text { Share of } \\
\text { household heads / } \\
\text { Land-owners }\end{array}$ & Region / Country & Source \\
\hline \multicolumn{4}{|l|}{ Coffee sector } \\
\hline $70 \%$ & $20 \%$ & Global $^{+}$ & ITC, 2008 \\
\hline $\mathrm{n} / \mathrm{a}$ & $23 \%$ & Uganda & Meemken and Qaim, 2018 \\
\hline $\mathrm{n} / \mathrm{a}$ & $35 \%^{\ddagger}$ & Mexico \& Central America & Lyon et al., 2010 \\
\hline $\mathrm{n} / \mathrm{a}$ & $29-34 \% \S$ & Kenya & Dijkdrenth, 2015 \\
\hline $\mathrm{n} / \mathrm{a}$ & $24 \%$ & Uganda & Sekabira and Qaim, 2017 \\
\hline $\mathrm{n} / \mathrm{a}$ & $19 \%$ & Ethiopia $^{+}$ & \\
\hline $\mathrm{n} / \mathrm{a}$ & $28 \%$ & Uganda $^{+}$ & $\begin{array}{r}\text { Author's calculation based } \\
\text { on World Bank LSMS-ISA }\end{array}$ \\
\hline $\mathrm{n} / \mathrm{a}$ & $26 \%$ & Tanzania $^{+}$ & \\
\hline \multicolumn{4}{|c|}{ Agricultural sector } \\
\hline $43 \%$ & $\mathrm{n} / \mathrm{a}$ & Global & \multirow{4}{*}{ FAO, 2011} \\
\hline $20 \%$ & $21 \%$ & Latin America & \\
\hline $50 \%$ & $17 \%$ & SE-Asia / S-Asia & \\
\hline $50 \%$ & $26 \%$ & Sub-Saharan Africa & \\
\hline
\end{tabular}

\footnotetext{
${ }^{+}$Study comprises 15 countries

* Share of female Fairtrade-organic farm operators

$\S$ Share of female coffee-cooperative members

${ }^{\dagger}$ Nationally representative sample
} 
Some studies suggest that female participation in production of export crops, such as coffee, may be lower than in other agricultural activities, especially subsistence farming. As entry barriers to access markets for export crops are usually high, there is a risk that women who have limited resources may be marginalized and forego opportunities to generate additional income (Maertens and Swinnen, 2012; Quisumbing et al., 2015). For example, for a sample of rural households in Uganda, Peterman et al. (2011) have shown that male-headed households are more likely than female-headed households to grow coffee.

Based on the available evidence, one can conclude that the role of women in coffee production is crucial and similar in significance to that in other agricultural sub-sectors. Accordingly, many of the findings from studies in the area of gender equality in the broader agricultural sector, which will be presented in this study, may be relevant to the coffee sector.

\subsection{Gender gap in coffee production}

While female participation in in rural households is indispensable, women face genderspecific constraints in accessing resources that hamper their agricultural productivity, negatively affecting household welfare (FAO, 2011). Significant differences exist between men and women in their level of empowerment and their capacity to exercise 'agency', i.e. to make effective choices and transform these choices into desired outcomes (World Bank, 2012). Expressions of agency include: control over resources; ability to move freely; decision making over family formation; freedom from the risk of violence; and the ability to have a voice in society and influence policy.

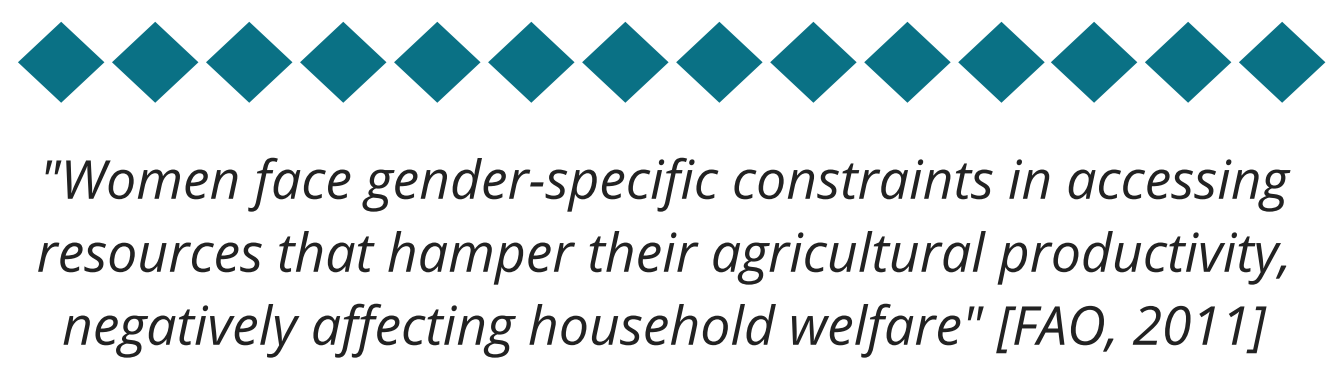

To understand the source and impact of gender inequalities in coffee-producing countries, a systematic mapping is required to assess the current state of women's empowerment across households, regions and countries. Recent years have seen the development of indices to measure the empowerment, agency and inclusion of women in the agricultural sector in order to establish a thorough understanding of the gender gap and to inform decision makers in the public and private sectors. The Women's Empowerment in Agriculture Index (WEAI), developed by the International Food Policy Research Institute (IFPRI), provides a comprehensive measure across five dimensions: decision about agricultural production; access to and decision-making power in the use productive assets; control over income; leadership in the community; and time allocation (Alkire et al., 2012). Countries are ranked according to their WEAl scores and divided into high (WEAl = 0.85 or higher), medium (WEAl = 0.73-0.84), low (WEAI = 0.72 or lower). 
The WEAI has significant data requirements that typically exceed standard household surveys. Where implemented, the WEAl shows a heterogeneous picture with regard to empowerment and gender parity, i.e. relative empowerment in dual households with male and female adults. A study of thirteen countries published in 2014, which included nine ICO exporting Members, showed women's empowerment ranging from low in Kenya, Ghana and Liberia to high in Rwanda and Uganda (Table 2). The cross-country study included only one Asian and one Latin American origin. The main driver of disempowerment in the sample of countries was access to and decisions about credit, workload and farmer group membership. Credit is the most important constraint in East Africa, while workload has a dominant influence in West Africa (Malapit et al. 2014).

While the WEAI methodology has not yet been widely applied to the coffee sector, recent years have seen increased interest by researchers and the coffee industry in the use of the indicator as a mapping tool (see also Box 1). For example, a recent study by Dietz et al. (2018) using a sample of coffee farmers in Honduras, found that women in the study area were significantly disempowered, with a WEAl of 0.75 placing them at the lower end of the Medium ranking. The findings are in line with the country-level results of the IFPRI study. The drivers of disempowerment in the sample of coffee farmers are lack of control over use of income and low access to and decision on credit.

Table 2: Women's empowerment in agriculture in selected ICO countries (2014)

\begin{tabular}{cccc}
\hline Country & Region & WEAI & Ranking \\
\hline Rwanda & East Africa & 0.91 & High \\
Uganda & East Africa & 0.86 & High \\
Malawi & Southern Africa & 0.84 & Medium \\
Nepal & Asia & 0.80 & Medium \\
Zambia & Southern Africa & 0.80 & Medium \\
Honduras & Latin America & 0.75 & Medium \\
Kenya & East Africa & 0.72 & Low \\
Ghana & West Africa & 0.71 & Low \\
Liberia & West Africa & 0.69 & Low \\
\hline
\end{tabular}

Countries are ranked according to their WEAl scores and divided into high (WEAI $=0.85$ or higher), medium (WEAl $=0.73-0.84)$, low (WEAI $=0.72$ or lower)

Source: Based on Malapit et al. (2014) 
Various studies support these findings on relative disempowerment and provide additional insights. For example, an analysis of intra-household labour allocation suggests that female household members devote disproportionally more time to cultivation and harvest of coffee than men, who focus on less time-consuming crop storage and marketing activities. Due to their involvement in selling the coffee, male household heads often also control the revenues from coffee production (Bolwig, 2012).

In Uganda, a stark contrast can be found in involvement in coffee production between female household heads, who manage the coffee production as part of an agricultural enterprise, and female adults in male-headed dual households. Only a third of the female adults claimed to be responsible for coffee production, compared to more than 90\% of male household heads (Meemken, Veettil and Qaim, 2017).

Similar patterns were identified by Avila and Useche (2016) in Colombia, where women in male-headed households participate less in the decision-making process in coffee production than in female-headed households. For Ecuador, they also find that women have less of a say in production decisions, albeit the differences are not statistically significant.

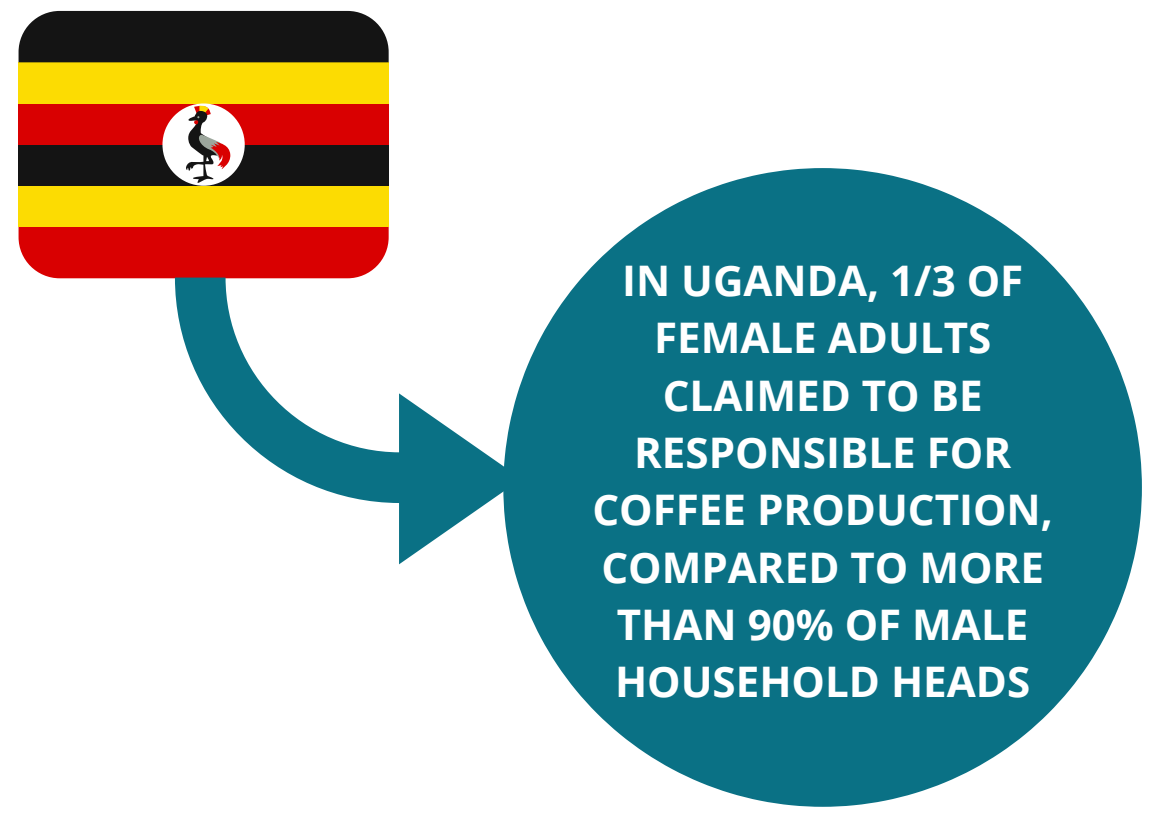




\section{Case study 1: Fostering gender equality through evidence-based supply chain interventions}

Recognizing that gender equality is a key concern and driver of coffee sustainability, Nespresso has developed a gender equality strategy for its AAA Sustainable Quality ${ }^{\mathrm{TM}}$ Program, that works with 75,000 coffee farmers in 12 countries. A basic premise of this strategy is that the AAA Program will implement strategies that increase women's empowerment and reduce gender disparities, and will not inadvertently perpetuate gender inequality, or worsen discrimination against women. In order to achieve these objectives, Nespresso asked TechnoServe to provide support in developing a field-tested gender tool, undertake rigorous data collection and conduct in-depth gender analysis. The next step was to generate insights to provide the basis for developing tailored, appropriate, and impactful interventions. TechnoServe and Nespresso AAA worked together to design a tailored gender analysis tool and then extensively field-tested this tool in selected AAA Clusters in Indonesia, Guatemala, and Ethiopia. The field team customized the tool to each Cluster and used it to collect a comprehensive set of both quantitative and qualitative data, using interviews and focus group discussions with over 250 randomly selected AAA farmers. The report explains the development of the tool and emphasizes elements which are critical to the success of the data collection process. The field-tested tool and proven approach provide a blueprint that Nespresso can use to generate insights to inform the design of impactful gender interventions in other AAA Clusters. By making this report available and sharing the analysis tool, Nespresso encourages other organizations working in coffee to conduct similar analysis in their supply chains, take actions to resolve gender disparity, and increase the empowerment of women in coffee farming.

The full report is available at: https://bit.ly/2OesEhz 


\subsection{The cost of disempowerment}

As a result of gender inequalities across dimensions of empowerment, the economic returns of women in agriculture are often lower than those of their male peers. Research has shown that women may harvest smaller crops and may be less likely to sell crops to markets, leading to lower farm income, negatively affecting rural livelihoods and household welfare (FAO, 2011; Croppenstedt et al., 2013).

For example, Diiro et al. (2018) found that WEAI scores on women's empowerment among smallholder maize farmers in Kenya are positively correlated with yield levels. Comparing productivity levels on female- and male-headed mixed crop family farms in Ethiopia, Tiruneh et al. (2001) found 35\% lower yields among women. Horrel and Krishnan (2007) found a similar yield differential between female and male farmers in Zimbabwe. Aguilar et al. (2015) recorded that in terms of output value per hectare, female-headed households in Ethiopia were $23 \%$ less productive than male-headed households. However, the magnitude of the gender gap varies across regions and production systems (Croppenstedt et al., 2013).

\section{$\mathrm{POPO}>\mathrm{OPO}$ \\ Women may harvest smaller crops and may be less likely to sell crops to markets leading to lower farm income, negatively affecting rural livelihoods and household welfare}

Evidence from the coffee sector is broadly in line with the findings for the overall agricultural sector. The analysis of World Bank census data shows that revenues from selling coffee are $39 \%$ and $44 \%$ lower for female-headed households in Ethiopia and Uganda, respectively. A gender gap in coffee revenues was also found for Tanzania, but the difference between male and female farmers was not statistically significant. Sekabira and Qaim (2017) report that the household income of female coffee producers in two regions in Uganda was $41 \%$ lower than that of male peers. There is evidence that the capacity for on-farm value addition may be one of the factors explaining gender differences in farm income across the sample of farmers. While $29 \%$ of male-headed households sold their coffee in green form, post-harvest processing was less widespread among female growers, who sold only $18 \%$ of their coffee in green form, likely resulting in a lower selling price. 
Similar to the findings for the agricultural sector more widely, the gender gap in the coffee sector may vary in magnitude across origins. Indeed, Avila and Useche (2016) found for a sample of coffee growers in Colombia and Ecuador that the yield in femaleheaded farms was only $2.5 \%$ lower and the difference not statistically significant. Also producer prices received by male and female farmers in the sample were similar. However, female-headed coffee farms tended to be less diversified in terms of their crop portfolio and less frequently employed intercropping techniques.

The gap in agricultural productivity between male- and female-headed households is mainly the result of differences in access to resources. Inter-household differentials in agricultural and economic outcomes decrease or disappear when taking into account women's endowments, for example education, farm size, access to product and factor markets, credit and public services such as extension (Aguilar et al., 2014).

Empirical evidence on gender-related productivity differences within households confirms the existence of an intra-household gender gap. For example, studies from West Africa suggest that plots managed by men have higher yields than those of women. Udry et al. (1995) recorded 10-15\% lower yields achieved by women. Existing intra-household differences between male and female farmers are hence caused by other factors than household-level market access, for example women's decisionmaking power related to the use of productive resources available to the household.

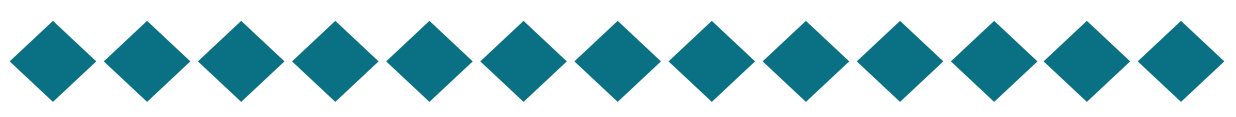

The gap in agricultural productivity between maleand female-headed households is mainly the result of differences in access to resources 


\section{GENDER GAP IN ACCESGING RESOURCES}

\subsection{Land and productive assets}

Land is the most important agricultural production factor and provides the basis for growing crops or holding livestock. Land, when farmed sustainably, can be passed on through generations, providing a livelihood for rural communities. Importantly, in areas with functioning property markets, land can also be used as collateral to obtain finance from commercial lenders. As such land ownership is vital to secure working capital loans and particularly finance for long-term investments in agricultural enterprises.

Evidence from the coffee sector is limited but a considerable gender difference in access to land still emerges. Table 3 compares information on landholdings of female- and maleheaded households from existing studies and based on the analysis of the World Bank census data. On average women own $25 \%$ less land than men, with the gap ranging from $20 \%$ in Uganda to $40 \%$ in Tanzania.

Table 3: Gender gap in access to land (by gender of household head)

\begin{tabular}{cccr}
\hline $\begin{array}{c}\text { Farm size } \\
\text { male (in ha) }\end{array}$ & $\begin{array}{c}\text { Farm size } \\
\text { female (in ha) }\end{array}$ & Region /Country & Source \\
\hline 1.05 & 0.84 & Uganda & Sekabira and Qaim, 2017 \\
2.34 & 1.85 & Colombia/Ecuador & Avila and Useche, 2016 \\
0.23 & 0.13 & Ethiopia & \\
1.06 & 0.75 & Uganda & Author's calculation based \\
0.84 & 0.51 & Tanzania & on World Bank LSMS-ISA \\
\hline
\end{tabular}

Note: All differences are statistically significant 
These findings are in line with previous research that has shown that, in the context of low- and middle-income countries, women have less access to land than men (Croppenstedt et al., 2013). For example, $45 \%$ of male headed households in rural Nicaragua own land, compared to only slightly more than $10 \%$ of households headed by women. In Vietnam, the differences are less pronounced, with land ownership rates of female- and male-headed households reaching $70 \%$ and $85 \%$, respectively.

Furthermore, male-headed households usually control larger land plots.

Where gender differences in land ownership are particularly stark, this is often the result of customary practices that limit access to and rights over land. Reasons explaining the differential are often country-specific and include male preference in inheritance, as well as marriage and male bias in land redistribution programmes (Deere and Leon, 2003; Melesse, Dabissa, and Bulte, 2017).

Besides lower land endowment, some studies find a significant difference in age of coffee trees between male- and female-headed households, which is likely to negatively affect productivity. Respondents in the study by Sekabira and Qaim (2017) report the average age of coffee trees on plots operated by women to be more than $8 \%$ higher, reflecting among other factors gender differences in access to finance for renovation and rehabilitation of coffee plantations. Similarly, in the context of Colombia and Ecuador, Avila and Useche (2016) report a 4\% difference in age of trees, which however is not statistically significant.

\subsection{Labour}

Agriculture, especially in the context of smallholder production systems, is labour intensive. The availability of labour in individual households depends on the size and composition of the household (number of family members in working age and gender) and the ability to hire labour. Research has shown that female-headed households are disadvantaged in both areas (FAO, 2011).

Households headed by women are on average smaller but contain a higher number of dependents. Analysis of World Bank census data shows statistically significant differences in size between male- and female-headed households in Ethiopia, Uganda and Tanzania (Figure 3). This is in line with findings by Avila and Useche (2016), who report that femaleheaded coffee-producing households in Ecuador are $13 \%$ smaller on average than male-headed households, resulting in lower labour availability.

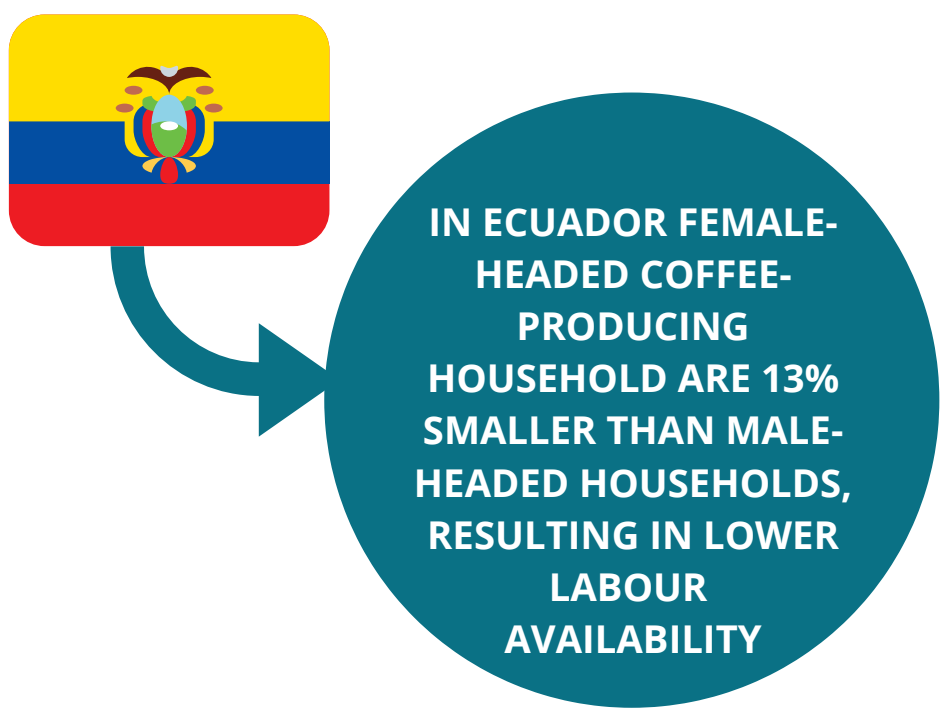


Furthermore, female household heads are often subject to the double burden of domestic tasks and farming activities, with unequal time allocation being identified to be a main driver of disempowerment (Alkire et al., 2012; Dietz et al., 2017). Figure 4 shows, for a representative sample of Ethiopian coffee farmers, that female household heads spent 4.9 hours per week on average on household chores, such as fetching water and collecting firewood, compared to only 1.5 hours per week for male household heads. Hence, it is not surprising that during the survey period, male farmers were reported to dedicate around $50 \%$ more time to agricultural activities than female farmers. Time constraints are also binding for women in male-headed households, which partially explains the lower use of labour in plots managed by women in male-headed households (Udry et al., 1995).

Figure 3: Number of household members (by gender of household head)

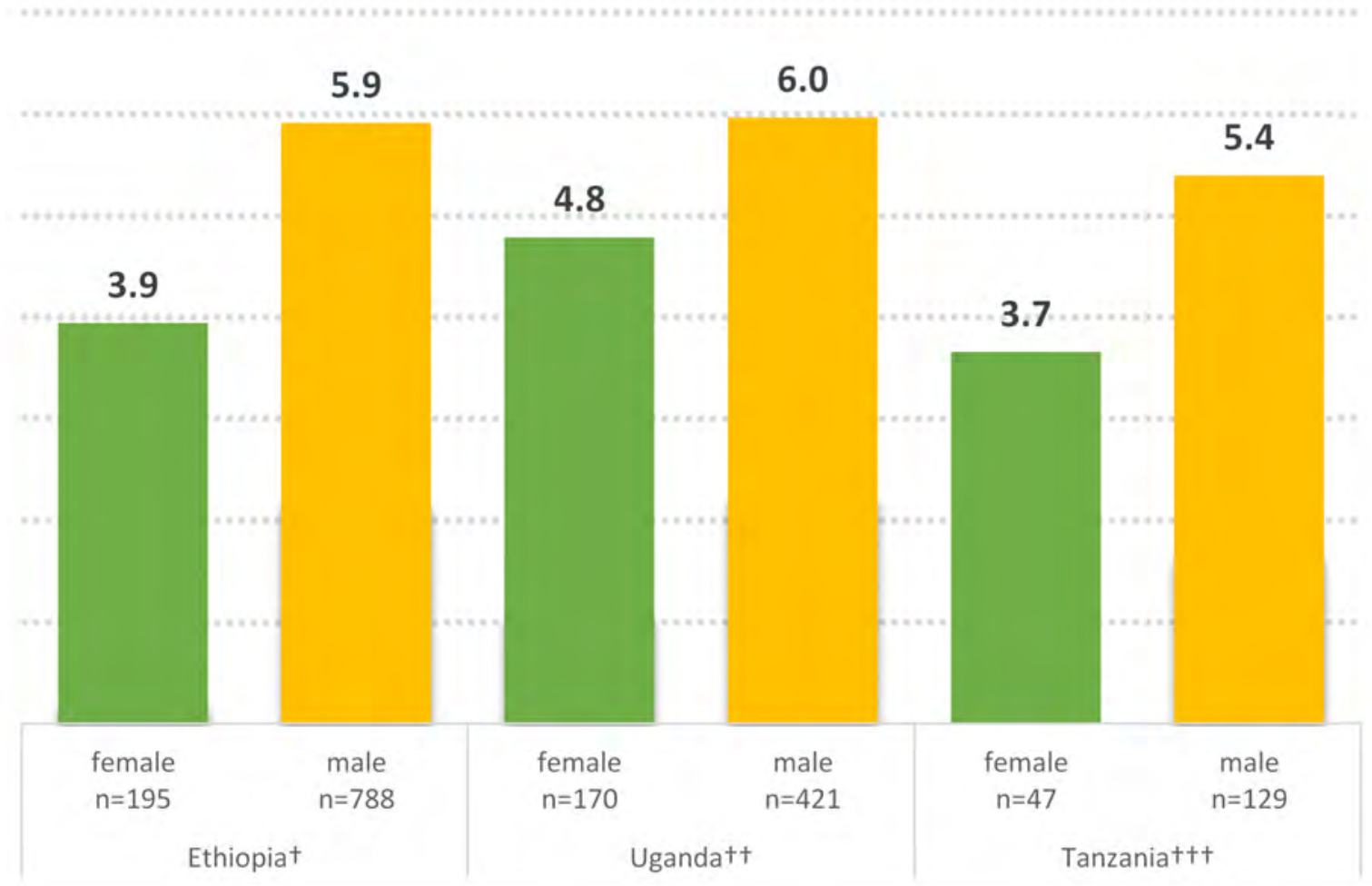

† Survey period: 2015

†† Survey period: 2013

†† Survey period: 2014

Source: Own calculations based on World Bank LSMS-ISA 
Figure 4: Time spent on household chores among Ethiopian farmers

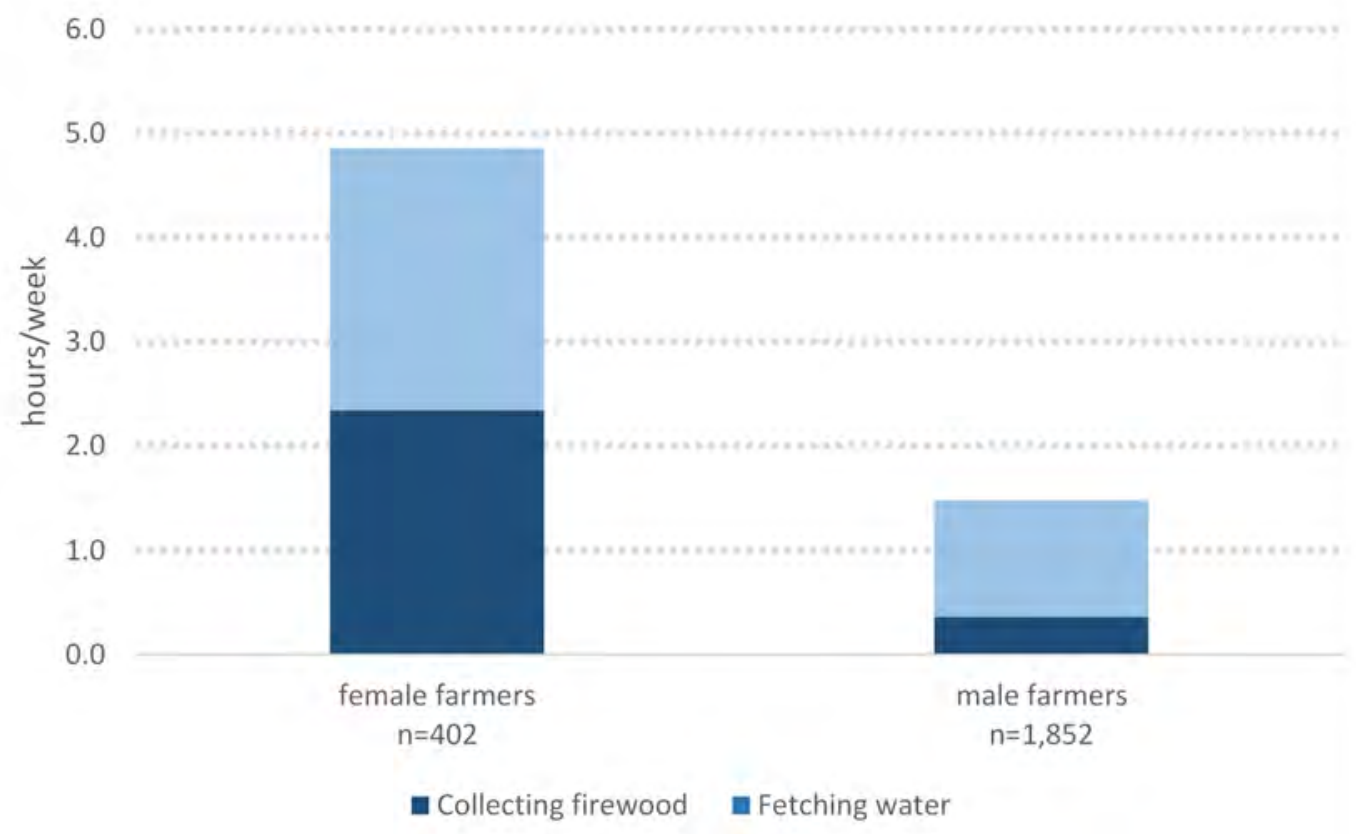

Source: Own calculations based on World Bank LSMS-ISA survey waves 2011, 2013, 2015

In accessing labour markets female farmers can be held back by social norms. For example, Hill and Vigneri (2014) found for cocoa producers in Ghana that female growers face constraints in accessing labour through gendered labour exchange groups, which is especially problematic for physically demanding farm work. In other cases, female farmers may receive help from men in the community, but only after the men completed work on their own plots (FAO, 2011).

\subsection{Education}

The level of education, considered as part of human capital endowment, is a main determinant of the productive capacity of households (World Bank, 2012; FAO, 2011). A strong correlation exists between the average level of education of working-age adults in rural households and agricultural productivity. Differences in access to education and educational attainment can be observed between men and women.

In their study of Ugandan coffee-producing households, Meemken, Veettil and Qaim (2016) provide evidence on differences in human capital of male household heads, female household heads and female adults (e.g. the wife) in male-headed households. They find that both female household heads and women in male-headed households have fewer years of formal education and lower rates of literacy. A similar pattern exists in a sample of family farms in Colombia and Ecuador, where male household heads had on average 4.05 and 6.43 years of schooling, respectively, compared to 3.27 and 5.27 years for female household heads (Avila and Useche, 2016). 
Analysis of World Bank census data confirms significant differences in school attendance between male and female household heads in East Africa. While 54\% of male respondents in Ethiopia received formal education, only $14 \%$ of women ever attended school. For Uganda the school attendance of female and male household heads was higher with $66 \%$ and $92 \%$, respectively. In Tanzania differences in formal education are less pronounced and not statistically significantly different, with $84 \%$ of male and $74 \%$ of female coffee producers reporting to have attended school.

These findings are in line with the results of a cross-country study of 15 countries published by the FAO (2011), which found that a significant difference in years of schooling and literacy rates between male and female household heads was observed in almost every country. The sample includes coffee-producing countries, such as Bolivia, Ecuador, Ghana, Guatemala, Indonesia, Nepal, Nicaragua, Nigeria, Malawi and Vietnam. The notable exception where no gender gap in education was found is Panama. Overall, research has shown that over time there has been a trend towards closing the gap, but significant differences in progress between regions remain. Lower levels of education are often the result of a bias against girls in education.

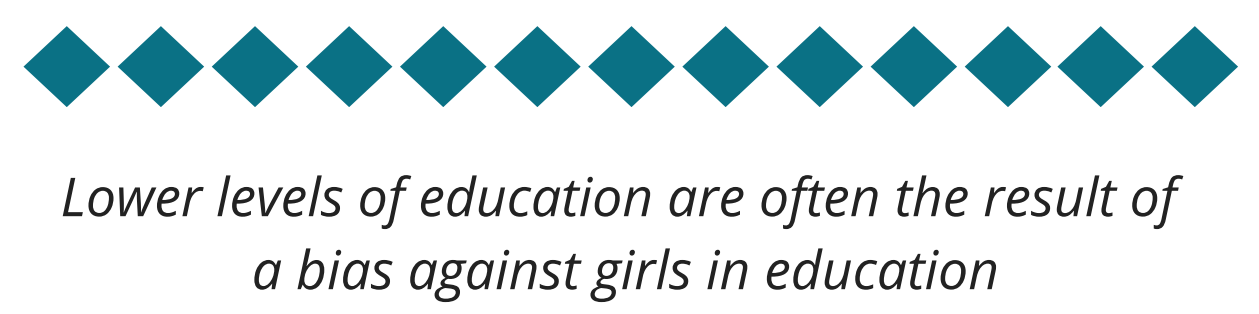

\subsection{Extension and training programmes}

Beyond basic education, differences also exist between male and female farmers in their access to agricultural knowledge and skills. For growers, agricultural extension, which in most countries is a public service, is often the main source of information on improved farming methods and new technologies (Croppenstedt et al., 2013).

Evidence from the coffee sector suggests that there is a gender difference in access to extension services, with women being less likely to receive visits from extension agents or to attend trainings. For example, survey data from a coffee-producing region in Uganda collected by Meemken, Veettil and Qaim (2017), which distinguishes between male farmers and their partners on the one hand and female farmers on the other hand, indicates a significant gender gap (Figure 5).

Within the sample of 453 coffee-producing households that were interviewed, $58 \%$ of male household heads attended training sessions. In comparison, only $46 \%$ of female farmers benefited from these skills transfer opportunities. The gender gap was even more pronounced within coffee-producing households, as less than $40 \%$ of female partners attended farmer trainings. 
Figure 5: Access to training among coffee farming households

male farmers $(n=326)$

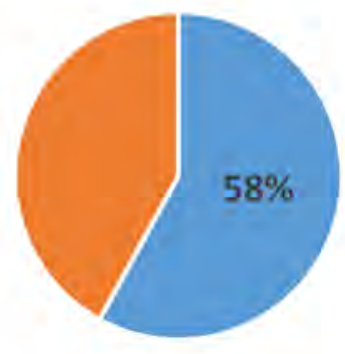

$=$ Attended training female farmers $(n=91)$

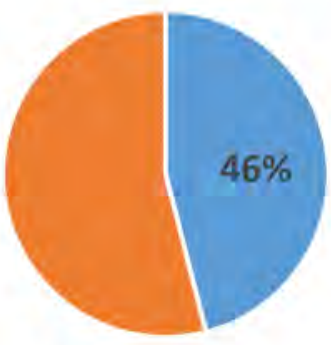

= Did not attend training female partners $(n=297)$

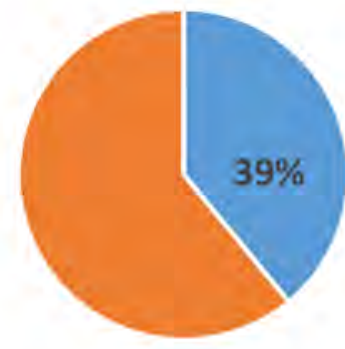

Source: Based on Meemken, Veettil and Qaim (2017)

The size of the gender gap in access to extension varies across regions. Avila and Useche (2016) found nine percentage points lower access for female farmers in Colombia with low statistical significance. No gender difference was found in the same study for neighboring Ecuador.

This evidence from the coffee sector is broadly in line with findings for other agricultural producers. A survey in India revealed that $29 \%$ of land-holding male-headed households received an extension visit, compared to only $18 \%$ of female-headed households (World Bank and IFPRI, 2010). The same study showed a similar pattern in Ethiopia, with $28 \%$ of male-headed households having access to extension services, whereas only $20 \%$ of female-headed households were visited by an extension worker.

A number of factors determine women's lower access to information on farming techniques. For example, a male bias often appears to exist in service provision based on the belief that men are decision makers and female farmers only marginal producers. Larger farms, which tend to be operated by men, are more likely to be targeted by extension agents due to economies of scale and higher efficiency in service provision. Furthermore, time constraints related to the double burden of household tasks and farm work, as well as social norms affecting their mobility, may negatively affect women's ability to participate in farmer trainings (World Bank and IFPRI, 2010). 


\subsection{Input use}

The use of agricultural inputs to increase yields and achieve high quality is standard practice in modern agriculture. However, research on gender differentials in agricultural production shows that women use fewer certified seeds or seedlings, as well as less mineral and organic fertilizers and pesticides, than men in their farming enterprises. For example, Udry et al. (1995) found for a sample of farmers in Burkina Faso that the production intensity in plots managed by women is lower than in those operated by men.

The gender gap is largest between male-headed households and female-headed households without a male presence. In male-headed households with adult females in Malawi, for example, the differential in fertilizer use between male- and femalecontrolled plots is less pronounced (Uttaro, 2002).

Some of these differences in input use can be explained by the fact that women tend to farm crops that require less inputs, while men focus on cash crops that show higher returns to fertilizer and pesticide applications. Hence, the gender gap in input use may be smaller when directly comparing male- and female-operated coffee farms, effectively controlling for land use differences. The evidence from the coffee sector is mixed. For example, Sekabira and Qaim (2017) show that expenditures on inputs in coffee production incurred by women are $17 \%$ lower than those of their male peers (Figure 6 ).

Figure 6: Input use among Ugandan coffee producers by gender of household head (in thousand UGX/ha)

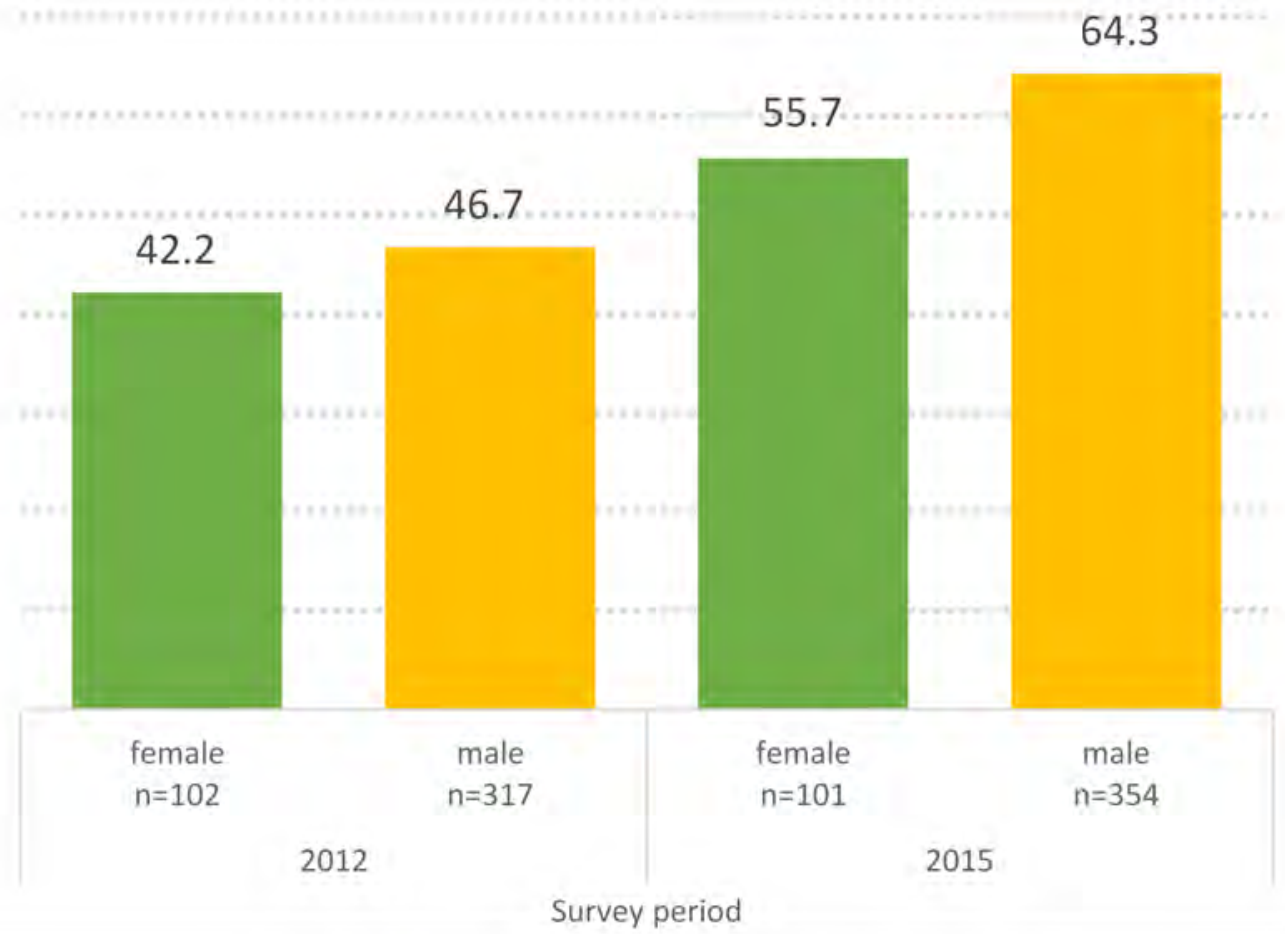

Source: Own calculation based on Sekabira and Qaim (2017) 


\subsection{Financial services}

Limited input use and lack of investment in modernization and expansion of agricultural enterprises can be the result of limited access to finance. Furthermore, formal and informal credit is vital for farmers to buffer income instability, typical in agricultural production with its high production risk due to weather shocks.

Meemken, Veettil and Qaim (2017) established that among Ugandan coffee producers $39 \%$ of male household heads have a personal savings account compared to only $26 \%$ of their female partners and $24 \%$ of female household heads. Avila and Useche (2016) find no difference in access to credit between male and female coffee producers in Colombia and Ecuador. However, the survey covered access to credit as a binary variable and does not provide information on potential gender differences in loan sizes.

Existing evidence from the coffee sector is broadly in line with patterns found in the agricultural sector more widely. In most low- and middle-income countries a profound gender gap exists in access to financial services. Survey data has shown that femaleheaded households are less likely to use credit than male-headed households, negatively affecting women's economic efficiency (Croppenstedt et al., 2013). The main reasons for difficulties in obtaining formal credit are lack of sufficient collateral (women on average own smaller land plots or lack formal titles), as well as lower education and financial literacy. Furthermore, behavioral differences (women tend to be more risk averse), cultural norms and family responsibilities seem to be not fully compatible with the design of available financial products and service delivery models (Fletschner and Kenney, 2014). Limited access to informal credit on the other hand compared to their male peers can be partially explained by structural differences of women's social networks.

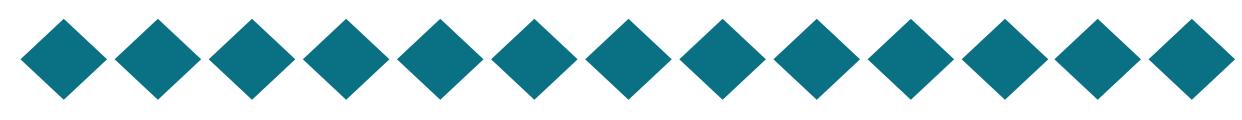

Female-headed households are less likely to use credit than male-headed households, negatively affecting women's economic efficiency 


\subsection{Social capital}

Community-based organizations, such as farmers' groups, clusters, co-operatives or savings associations, are an effective way of improving access to factor and product markets, information about production techniques and to pool risk. Collaboration of individual farmers helps to overcome constraints in accessing resources and to realize economies of scale (FAO, 2011).

However, women often struggle to actively participate in farmer organizations, since prevailing social norms, time constraints and limited mobility as a result of the double burden of household and field work limit their participation. For example, in the context of two coffee producing regions in Uganda, Meemken, Veetil and Qaim (2017) found a significantly lower participation in group meetings among female farmers compared to their male peers (Figure 7).

Figure 7: Participation in farmer group meetings among coffee farmers in Uganda

male farmers $(n=326)$

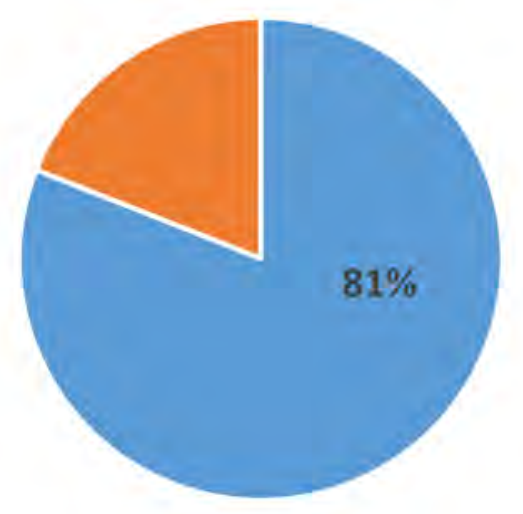

- Participates = Does not participate female farmers $(n=91)$

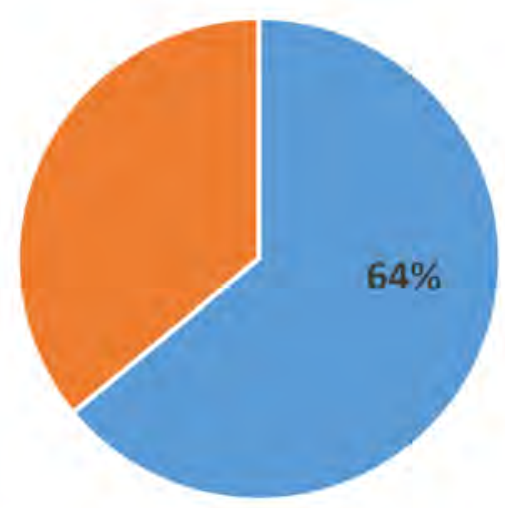

- Participates - Does not participate

Source: Based on Meemken, Veettil and Qaim (2017)

For the voice of women to be heard in mixed-sex groups, female household members need to be explicitly invited alongside the male household head. Also, women's role in the governance of organizations needs to be strengthened (Meinzen-Dick et al., 2010; FAO, 2011). Rural development interventions have also recognized women's groups as a useful way in overcoming constraints to participation in community-based organizations and to foster economic, political and social empowerment (Raghunathan, Kannan and Quisumbing, 2018). 


\section{Case study 2: Empowering women coffee farmers in a post-conflict situation}

Children and women are often the most vulnerable groups in armed conflicts. The UN Women Colombia initiative, together with the local NGOs Corporation for the Social, Technological and Economic Development of Colombia (CORPDESARROLLO), the URT and the Food and Agriculture Organization of the United Nations (FAO), implemented a project to support women in postconflict Colombia. Sixty women residents of the Tablón de Gómez Municipality in Nariño Department, Colombia, who were victims of the armed conflict and are participating in the land restitution process, received technical assistance to enable them to take the lead in designing a business plan for marketing green coffee and dry parchment coffee. The business idea also touches on alternative ways of boosting their income through a shop selling speciality coffees, a collection centre, and includes measures to effect cultural change focusing on campaigns on joint caring responsibilities and aspects of masculinity.

An important outcome of the project is that participating women improved their commercial expertise and their ways of adapting ideas for viable businesses by drawing up a business plan, and strengthened their organizational skills, gaining autonomy in the process. A partnership has been established with the Rural Development Agency (ADR) and the Land Restitution Unit (URT) to finance the business plans. 


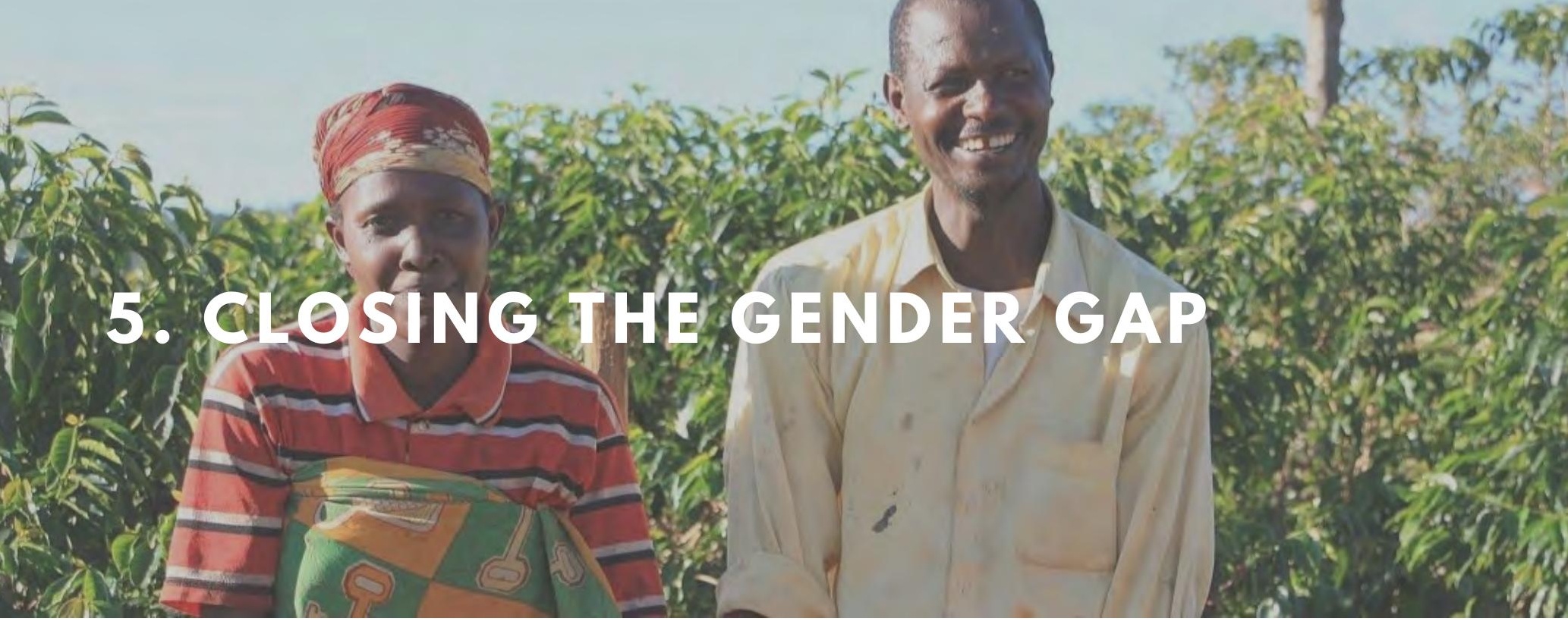

Closing the gender gap in agriculture would not only contribute to gender equality but also generate a wide array of social and economic benefits.

This chapter describes the impact on broader social development and provides an overview of the role the public and private sectors can play in implementing the global agenda for greater gender equality.

\subsection{Empowerment, productivity gains, increased resilience and wider economic benefits}

First and foremost, the empowerment of women involved in coffee production -female farmers, female household members in male-headed family farms and female farm workers - is positively correlated with the ability to exercise agency and influence their life matters. Hence, empowerment is instrumentally linked to women's own wellbeing and that of their families and dependents (World Bank, 2012).

Equal access to resources, ranging from human capital to production factors, would enable female farmers to produce more efficiently, resulting in higher output and income. Closing the gender gap in access to resources in low-income countries would boost global agricultural output by $2.5-4 \%$, translating into higher farm income and improved household welfare (FAO, 2011). While the coffee sector may also benefit from higher productivity and increased value addition, the magnitude of the gains is likely to vary across region, depending on the size of the gender gap. Fostering gender equality will also crucially contribute to building female farmers' resilience to volatile coffee prices and their adaptive capacity to climate change, a main challenge faced by the sector (Jost et al., 2016).

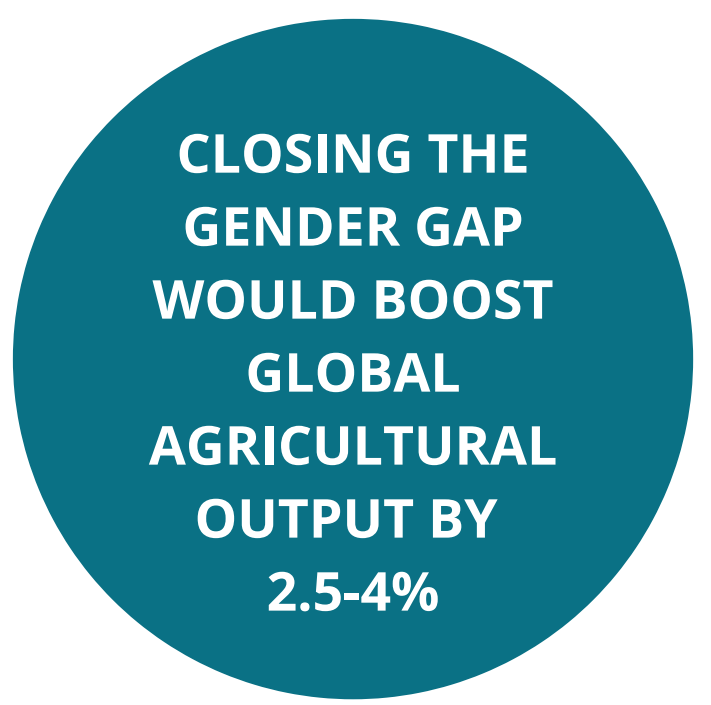


In fact, gender-sensitive adaptation strategies recognize women as key agents in building climate-resilient coffee communities. Broad-based investment in adaptation is required to meet future demand for coffee, as estimated consumption will increase by $\mathbf{4 0}$ to 50 million bags by the year 2030, if the current growth trend continues.

Female empowerment, improved productivity and resilience against economic shocks stemming from volatile coffee markets as well as the impact of climate change result in wider social and economic benefits for rural families and communities. Higher and more stable farm incomes, as well as an increased female say in household decisions, are associated with better nutritional and health status of children as well as higher shares of income spent on education (Doss, 2013; Malapit and Quisumbing, 2015; Sekabira and Qaim, 2017). Hence, fostering gender equality in the coffee sector directly contributes to the 2030 Agenda for Sustainable Development.

\section{Case study 3: Fostering engagement of women in farmer organizations and cooperatives}

Wet processing of coffee cherries improves the quality of green coffee, enabling farmers to fetch a premium on the sales price and to increase their income. However, leadership of co-operatives operating wet mills is male-dominated. In Ethiopia, Technoserve, a not-for-profit organization, works with 96 coffee farmer organizations to integrate gender into the institutional structures of cooperatives. Based on insights from a project-focused gender analysis, all project staff were trained on gender integration and given gender responsibility. In addition, select staff, called "Gender Leads", were given greater gender integration responsibility. These Gender Leads carried out discussions with cooperative and government leaders on the value of increased female participation; spoke to women about the benefits of involvement in cooperative membership and leadership; and successfully negotiated for new female members to be able to pay cooperative membership fees in installments. The cooperatives were also actively supported to select a "Women's Representative", who then joined cooperative meetings to participate in discussions on the organization's activities, distribution of benefits, and control of cooperative resources. In addition, cooperative female leaders were given capacity building on active participation, decision making, leadership and entrepreneurship. In the two years since the programme started, these interventions have had a significant impact. The male-dominated leadership of all project cooperatives created and delivered a gender policy with self-determined baselines, gender targets and action plan. The consistent monitoring of female participation has shown that 3,619 women, for the first time in their lives, have become cooperative members (increasing total female membership by $25 \%$ ) and an additional 114 women have become cooperative leaders, resulting in a doubling of the number of women in leadership. 


\subsection{Closing the gap - a role for the public and private sectors}

There is a role for both the public and the private sectors in closing the gender gap in coffee production. Today, more and more rural development programmes and supply chain policies include women, either explicitly as a target group or implicitly through gender mainstreaming (Doss, 2013). Depending on the objectives of specific programmes, women can be reached, benefitted or empowered (Johnson et al., 2017). Programmes that reach women include them as participants (e.g. via quotas) but do not comprise design features that consider women's needs and constraints. Programmes aiming at women's empowerment try to change the underlying power balance between men and women in order to achieve benefits that are sustainable.

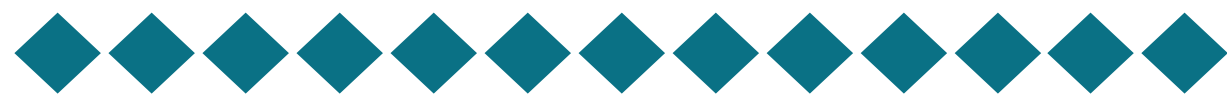 \\ There is a role for both the public and the private sectors in closing the gender gap in coffee production}

\section{Case study 4: Value chain cooperation for gender impact}

Collaboration of value chain actors is a way to pool resources for sustainable supply chains and gender impact. British retailer Marks and Spencer, mid-sized roasters Taylors of Harrogate and Matthew Algie, together with the not-forprofit organization TWIN, implemented a project in Peru that addresses the challenge of climate change adaptation, focusing on sustainable agriculture, gender equity and opportunities for the younger generations. Working with two cooperatives and directly benefitting 1,250 farmers and their families, the project employs a gender-sensitive approach to increase participation of women in training on sustainable farming techniques, including production and use of organic fertilizer, renovation and rehabilitation as well as shade and water management. Furthermore, using the Gender Action Learning System (GALS) methodology, women can feel more empowered within their households or get prepared to take on leadership roles in producer organizations and community-based organizations. The programme design and implementation considers that increasing women's access to knowledge on coffee production and empowerment are objectives that are mutually reinforcing. 
Within the realm of public policies, a distinction can be made between policies that are specific to the agricultural or coffee sector and those that address universal challenges. For example, access to primary education has been shown to be positively correlated with the productive capacity of households. Hence, public policies aiming at reducing the male bias in education and increasing female school enrollment in rural areas will benefit coffeeproducing households. Among the policies that are more specific to the agricultural sector are those concerned with property and land use rights, as well as those related to agricultural extension services. Interventions aiming at increasing financial literacy among farmers are often implemented by or in collaboration with non-governmental organizations (NGOs). The coffee industry on the other hand has been successful in implementing elevated private standards and gendered supply chain policies, driven by efforts to build sustainable supply chains and increased consumer awareness in social aspects of coffee farming.

The recognition of gender as a crucial element of rural development and sustainable agricultural supply chains by development organizations and the coffee industry, respectively, is increasingly reflected in the adoption of broad gender policies. These policies usually comprise reporting requirements for initiatives, programmes and projects (World Bank, 2015; GEF, 2017). The Common Measurement Framework, developed by the Partnership for Gender Equity (PGE) and the Global Coffee Platform (GCP), is a recent initiative from the coffee industry that enables value chain actors to track and communicate progress towards sustainability objectives (PGE-GCP, 2017). Measurement and reporting frameworks typically go beyond female participation rates, with a stronger emphasis on outcomes and impact along various dimensions of empowerment and agency on the one hand and economic dimensions on the other hand (Figure 8).

\section{Figure 8: From project to gender impact}

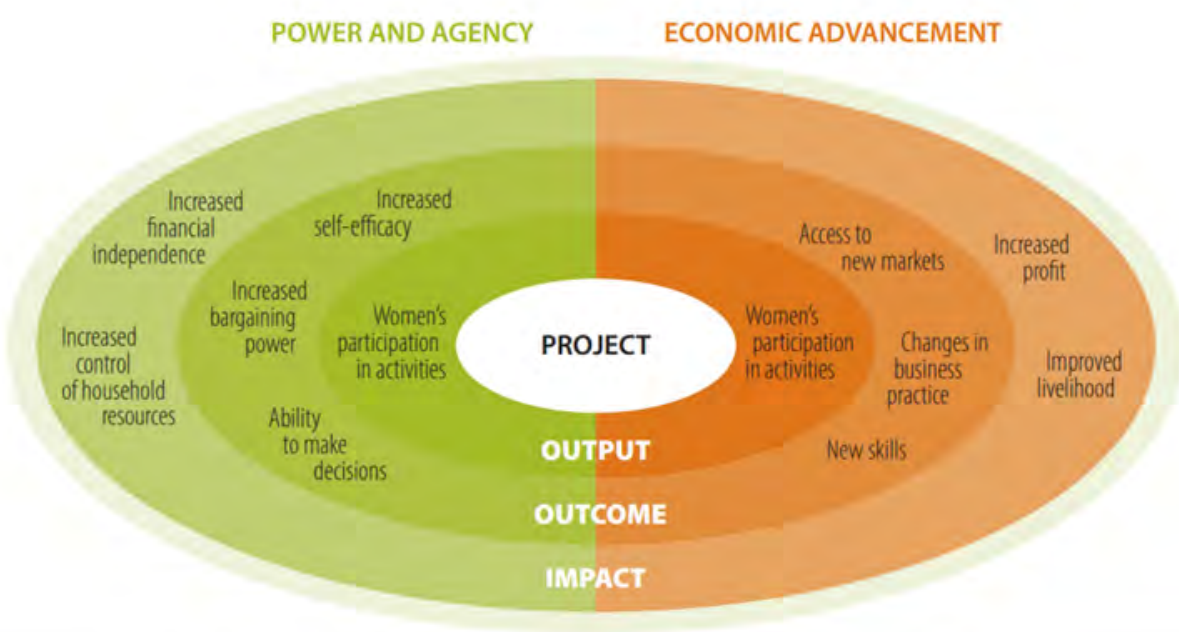

Source: From UNIDO, 2015

The following section will provide some examples of policies and interventions that may benefit female coffee producers by increasing their access to resources and rights with a view to empowering women and enabling them to participate in commercial and export-orientated agriculture. 


\subsection{Land certification and property rights}

Secure land tenure is crucial in promoting equitable and sustainable development (Melesse, Dabissa and Bulte, 2017). The gap in access to land between male and female farmers can be closed by eliminating discrimination under the law, while recognizing the importance and power of customary land rights, educating officials and evaluating them on gender targets, educating women regarding land rights, and adjusting bureaucratic procedures related to land registration (FAO, 2011). However, in regions with a legal tradition that already supports egalitarian inheritance, social norms also need to become more supportive in increasing gender equity in land inheritance (Deere and Leon, 2003).

Implementing joint ownership of land by husband and wives has proven successful in empowering women in male-headed households. Securing control over household assets improves the bargaining position of women vis-à-vis male household heads, ensuring that economic choices are made collectively. An analysis of the joint land certification programme suggests that issuance of joint ownership titles had a positive impact on women's empowerment and agency across a range of indicators (Melesse, Dabissa and Bulte, 2017).

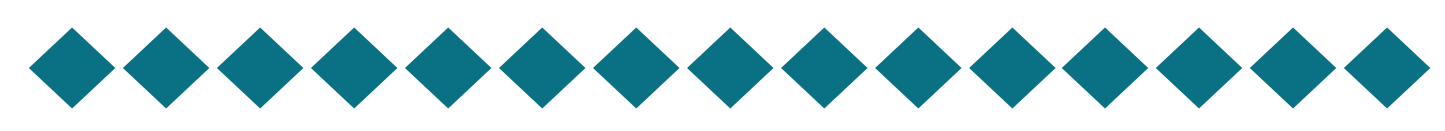

The gap in access to land between male and female farmers can be closed by eliminating discrimination under the law

\subsection{Extension}

A gender-sensitive approach to agricultural extension and farmer schools can address the factors limiting women's access to information on farming techniques and new technologies. Well designed extension programmes take into account the cultural, time, mobility and educational constraints faced by female farmers (Croppenstedt et al., 2013).

For example, in some contexts it is more appropriate for female farmers to interact with female extension agents. This is not a universal preference and depends on prevailing cultural norms, but increasing the share of female extension workers helps to deliver services more effectively, as evidence from Tanzania shows (Due, Magayane and Temu, 1997). Sensitizing male extension agents about the situation of rural women with calibration of training contents can have positive results, for example, increasing the share of women receiving extension visits and the effectiveness of transfer of information and skills. The spread of mobile phone technology provides an additional channel for dissemination of information to women that could gain importance in the future (Croppenstedt et al., 2013). 


\section{Case study 5: Effectively including women in farmer training and extension}

Female attendance at agronomy trainings is often low. The Coffee Initiative, a project carried out in East African countries funded by the Bill \& Melinda Gates Foundation, integrates contextappropriate strategies for gender equality across its "Farm College" activities to increase women's ability to benefit from targeted improvements in coffee agronomy. The project partners have developed strategies to actively recruit and retain women for the program by employing the following principles:

- Actively recruit women as Farmer Trainers. The project achieved an average of 40\% across East Africa.

- Speak to community leaders and get their active support for both female and male participation in trainings.

- Guide the focal farmer group election process to ensure that either the focal farmer or the assistant focal farmer is a woman.

- Fully include women in all Farm College activities in a way that makes them feel comfortable, valued and respected.

- Sensitize men on the benefits of women from their household enrolling and attending trainings.

- Invite husbands and wives (who attend training together) to explain to others how attendance by both of them benefits their family.

- During the farmer registration process invite two individuals from each household to sign up - one man and one woman. If only a man signs up, encourage him to invite his wife to training.

Farmer Trainers solicit input from women and select training times that take into account women's time and work burdens. Women are also specifically encouraged to bring their children to trainings to reduce the chance that childcare prevents attendance.

After the introduction of targeted approaches to encourage women participation in trainings, the attendance rate in the project area in Tanzania increased from $20 \%$ to $40 \%$

\subsection{Financial literacy and access to finance}

Closing the gender gap in access to financial services requires overcoming customary restrictions that prevent women from holding bank accounts, as well as increasing financial literacy through specific training programmes, encouraging the formation of communitybased organizations, such as women's groups (FAO, 2011). 
Development organizations in partnership with development banks often fill the gap by providing training to strengthen the internal financial management of smallholder organizations. For example, a project carried out in the coffee sectors of Costa Rica, El Salvador, Guatemala, Honduras, Nicaragua, and Mexico organized 239 workshops and reached almost 6,000 participants, 31\% of them women. Evaluation has shown that the project was successful in increasing financial literacy of farmer organization members, and in increasing lenders' awareness for opportunities in relation to financing small farmers (ICO and World Bank, 2015).

Microfinance, the extension of loans to the very poor, has been recognized as important enabler of economic development, proven to be successful in benefitting women. A recent study of 64 low-income countries has shown that increasing access to microfinance by $15 \%$ would reduce inequality, as measured by the UN-GII, by as much as $50 \%$ on average (Zhang and Posso, 2017).

Technical innovation, such as mobile money, can alleviate some of the constraints faced by women in accessing finance, e.g. the need to travel long distances and social norms that affect the ability to interact with financial institutions (Duncombe, 2009; Fletschner and Kenney, 2014). However, a gender gap in accessing mobile money services could prevent women from benefiting from these technical innovations, with negative implications for financial inclusion. Sekabira and Qaim (2017) have found, for a sample of coffee farmers in Uganda, that only $47 \%$ of female household heads used mobile money services, as compared

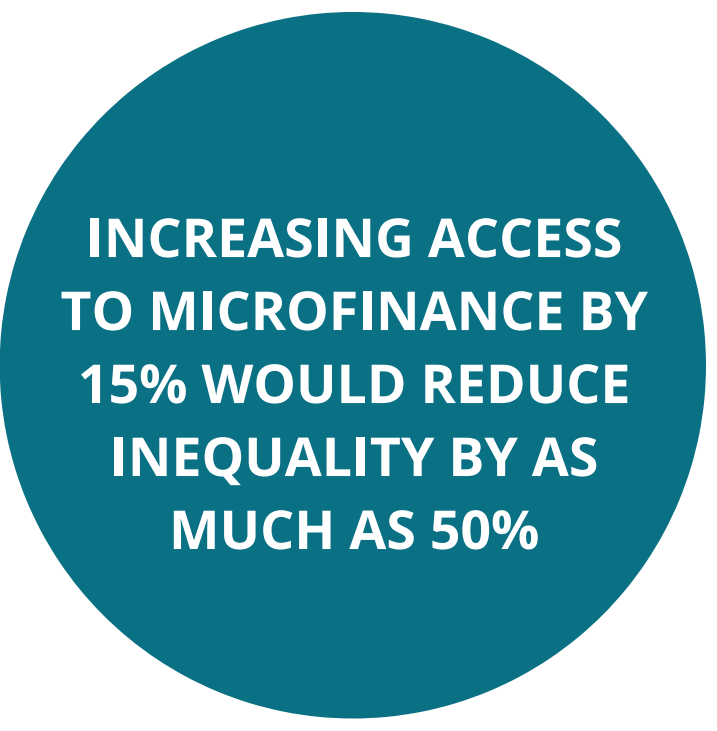
to $67 \%$ for male household heads.

\subsection{Voluntary sustainable standards}

Closing the gender gap in access to financial services requires overcoming customary restrictions that prevent women from holding bank accounts, as well as increasing financial literacy through specific training programmes, encouraging the formation of communitybased organizations, such as women's groups (FAO, 2011).

Voluntary sustainability standards and certification schemes can have a positive effect on gender equality. Promoting sustainability, standards are concerned with a range of issues related to farming practices, environmental, and social issues. The latter encompass labour conditions and wider development issues, including gender equality. Standards may require farmer organizations to comply with non-discrimination policies and organize compulsory gender-awareness workshops and agricultural trainings that are tailored to female farmers (Meemken and Qaim, 2018). 
In terms of the impact at household level, certification schemes with a gender component can mitigate some of the negative consequences stemming from agricultural commercialization. For example, women in certified households have significantly more control of coffee production and income derived than women in noncertified households (Chiputwa and Qaim, 2016).

\section{Case study 6: Sustainability standards, certification and gender impact}

Voluntary sustainability standards (VSS) can be an effective way to promote environmentally and socially sustainable coffee production.

The approach of Utz \& Rainforest Alliance to foster gender quality and women's empowerment is based on two pillars. First, the Code of Conduct contains requirements on non-discrimination, equal pay for equal jobs, and encouraging women to actively participate in workers' and farmers' organizations. Especially for plantations, there are also additional provisions related to, for example, the right to maternity leave and the right for women to return to their jobs under the same conditions after having children. In addition to the Code of Conduct, Utz \& Rainforest Alliance advocates with key stakeholders in order to disseminate knowledge on the impact of gender inequality and to highlight best practice examples that can help addressing these issues.

Fairtrade International sets basic rules for their trading system that contain provisions specifically designed to prevent gender inequality and rules barring Fairtrade-certified organizations from engaging in behaviour that is sexually intimidating, abusive or exploitative. Additional gender impact derives from providing leadership and management courses to female farmers and training of female extension workers, overcoming established social norms and empowering women. The premium received by Fairtrade producers may be used to support gender equality, e.g. to fund activities at level of cooperatives.

On the other hand, building awareness through mandatory gender workshops can gradually change social norms and established perceptions about the role of women in rural societies. Hence, private initiatives can complement gendered public policies and the positive attitudes shown by women towards certification schemes does not come as a surprise (Meemken, Veettil and Qaim, 2017).

However, time constraints resulting from the double burden of household and farm work can restrict women's active participation in producer groups. Hence, the governance and policies of the groups should be structured in a way to facilitate ample organizational participation of women (Lyon, Muterbaugh and Worthen, 2017). 


\subsection{Information and communication technology}

Increasing use of mobile phones in rural areas of low-income countries can have a positive impact on broader social development, including gender equality, especially in Sub-Saharan Africa. A clear link exists between the use of mobile phones and farm-level economic indicators, such as agricultural input and output prices, yields and profits. The use of mobile phones enables farmers to compare prices, improving transparency in remote agricultural markets. Farmers can receive agronomic advice and timely warnings about spreading pests and plant diseases, informing production decisions (Aker, 2010; Aker and Ksoll, 2016).

A recently published article suggests that mobile phone use improves women's agency and fosters empowerment (Sekabira and Qaim, 2017). The authors found that, for a sample of Ugandan coffee farmers, in households where at least one female adult uses a mobile phone, the proportion of total household assets co-owned by women is $21 \%$ higher than in households where mobile phones are used exclusively by men. Besides higher female participation and more influence in household decisions, nutritional benefits for dependents in the household are associated with gendered mobile phone use, as suggested by indicators focusing on food security and dietary quality.

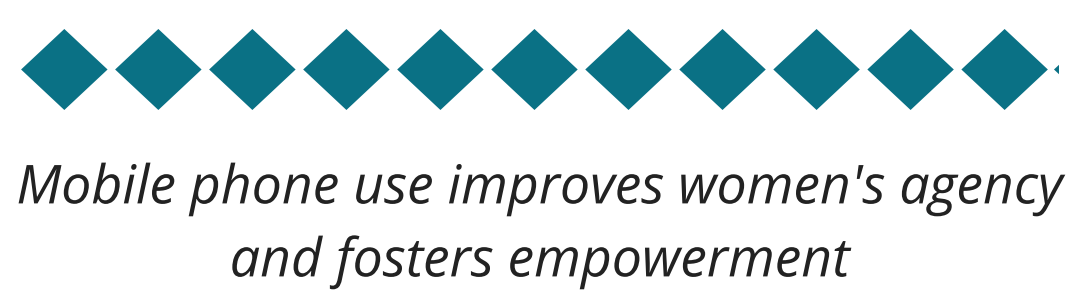

\subsection{Complementarities}

The reasons for the existing gender gap in the coffee sector are various. Potential responses to close the gender gap range from public policies to NCO-driven interventions and gendered supply chain policies of the coffee industry. Research has shown that female growers' productivity is hampered by various factors simultaneously. Alleviating only one constraint at a time may lead to suboptimal outcomes if other constraints remain binding. For example, yield increases from improved access to inputs could be suboptimal if the farmers lack the skill and training to optimally apply fertilizers and pesticides. Only if both use of inputs and access to extension is facilitated, yield levels and hence economic outcomes may change.

Hence, policies and programmes simultaneously addressing multiple existing constraints can show strong complementarities (FAO, 2011). Coordination of efforts made by the diverse actors in the coffee sector could increase the effectiveness of specific interventions. Programmes that aim at benefitting and empowering women will ensure that positive economic and social impact is sustainable (Johnson et al., 2017). 


\section{Proposed next steps for the International Coffee Organization}

- Disseminate findings of this report to stimulate discussion and continue to provide the forum for exchanges of views on coffee sector development and advocacy for gender equality for the public and private sectors.

- Recognize gender as cross-cutting theme and include gender dimension in future research on annual themes as well as other analytical work.

- Extend the gender analysis beyond the farm levels so as to cover the whole coffee value chain, including trading, roasting, retail and consumer levels.

- Harness public-private partnerships to collect data and measure progress towards achieving the SDC of gender equality.

- Gender Mainstreaming[5] by ensuring that all development projects and initiatives supported by the ICO aim to address and provide solutions to reduce the gender gap in the coffee sector.

5. 'Mainstreaming a gender perspective is the process of assessing the implications for women and men of any planned action, including legislation, policies or programmes, in any area and at all levels. It is a strategy for making women's as well as men's concerns and experiences an integral dimension in the design, implementation, monitoring and evaluation of policies and programmes in all political, economic and societal spheres so that women and men benefit equally and inequality is not perpetuated. The 


\section{Bibliography}

Aguilar, Arturo, Carranza, E., Goldstein, M., Kilic, T., and Oseni, G. "Decomposition of gender differentials in agricultural productivity in Ethiopia." Agricultural Economics 46.3 (2015): 311 334.

Aker, Jenny C., and Isaac M. Mbiti. "Mobile phones and economic development in Africa." Journal of Economic Perspectives 24.3 (2010): 207-32.

Aker, Jenny C., and Christopher Ksoll. "Can mobile phones improve agricultural outcomes? Evidence from a randomized experiment in Niger." Food Policy 60 (2016): 44-51.

Alkire, Sabina, Meinzen-Dick, R., Peterman, A., Quisumbing, A., Seymour, G., and Vaz, A. "The women's empowerment in agriculture index." World Development 52 (2013): 71-91.

Avila-Santamaria, Jorge, and Pilar Useche. "Women's Participation in Agriculture and Gender Productivity Gap: The Case of Coffee Farmers in Southern Colombia and Northern Ecuador." 2016 Annual Meeting, July 31-August 2, 2016, Boston, Massachusetts. No. 236156. Agricultural and Applied Economics Association (2016).

Bolwig, Simon. "Poverty and gender effects of smallholder organic contract farming in Uganda." (2012).

Chiputwa, Brian, and Matin Qaim. "Sustainability standards, gender, and nutrition among smallholder farmers in Uganda." The Journal of Development Studies 52.9 (2016): 1241-1257.

Croppenstedt, Andre, Markus Goldstein, and Nina Rosas. "Gender and agriculture: inefficiencies, segregation, and low productivity traps." The World Bank Research Observer 28.1 (2013): 79-109.

Deere, Carmen Diana, and Magdalena Leon. "The gender asset gap: Land in Latin America”. World Development 31.6 (2003): 925-947.

Deere, Carmen Diana, Gina E. Alvarado, and Jennifer Twyman. "Gender inequality in asset ownership in Latin America: Female owners vs household heads." Development and Change 43.2 (2012): 505-530

Demura, Shinichi, et al. "Gender differences in coffee consumption and its effects in young people." Food and Nutrition Sciences 4.07 (2013): 748.

Dietz, Thomas, Estrella Chong, A., Font Gilabert, P., and J. Grabs. "Women's empowerment in rural Honduras and its determinants: insights from coffee communities in Ocotepeque and Copan." Development in Practice 28.1 (2018): 33-50 
Diiro, G. M., Seymour, G., Kassie, M., Muricho, G., \& Muriithi, B. W. Women's empowerment in agriculture and agricultural productivity: Evidence from rural maize farmer households in western Kenya. PloS one, 13.5 (2018).

Dijkdrenth, Eveline. "Chapter 7 Gender equity within Utz certified coffee cooperatives in Eastern Province, Kenya."Coffee certification in East Africa: impact on farms, families and cooperatives. Wageningen Academic Publishers (2015): 489-502.

Doss, Cheryl. "Intrahousehold bargaining and resource allocation in developing countries." The World Bank Research Observer 28.1 (2013): 52-78.

Doss, Cheryl. "Data needs for gender analysis in agriculture." Gender in agriculture. Springer, Dordrecht, 2014. 55-68.

Due, Jean M., Flavianus Magayane, and Anna A. Temu. "Gender again-Views of female agricultural extension officers by smallholder farmers in Tanzania." World Development 25.5 (1997): 713-725.

Duncombe, R.A. and Boateng, R. Mobile phones and financial services in developing countries: A review of concepts, methods, issues, evidence and future research directions. Third World Quarterly 30 (2009): 1237-1258.

Fletschner, D., and Kenney, L. “Rural women's access to financial services: credit, savings, and insurance." Gender in agriculture Springer, Dordrecht (2014), (pp. 187-208).

Food and Agriculture Organization of the United Nations (FAO). Women in Agriculture. Closing the gender gap for development. State of food and agriculture 2010-11. Food and Agriculture Organization of the United Nations (2011) http://www.fao.org/3/ai2050e.pdf

GEF. Policy on Gender Equality, approved at the 53rd meeting of the Global Environmental Facility (2017) https://www.thegef.org//news/new-policy-genderequality-gef

Hill, Ruth Vargas, and Marcella Vigneri. "Mainstreaming gender sensitivity in cash crop market supply chains." Gender in agriculture. Springer, Dordrecht, (2014): 315-341

International Coffee Organization (ICO) and World Bank. "Risk and Finance in the Coffee Sector: A Compendium of Case Studies Related to Improving Risk Management and Access to Finance in the Coffee Sector." Joint report presented at the 114th session of the International Coffee Council in London, 2015. 
International Finance Corporation. "Investing in Women along Agribusiness Value Chains." Report by of the International Finance Corporation, Washington D.C., USA (2016).

International Trade Centre (ITC). "Women in Coffee”. International Trade Forum 3\&4 (2008): 32-33.

Horrell, S., \& Krishnan, P. “Poverty and productivity in female-headed households in Zimbabwe." The Journal of Development Studies, 43-8 (2007):1351-1380.

Johnson, Nancy L., et al. "How do agricultural development projects aim to empower women? Insights from an analysis of project strategies." Vol. 1609. International Food Policy Research Institute (2017).

Jost, C., Kyazze, F., Naab, J., Neelormi, S., Kinyangi, J., Zougmore, R., \& Nelson, S. "Understanding gender dimensions of agriculture and climate change in smallholder farming communities." Climate and Development, 8.2 (2016): 133-144

Klasen, Stephan. "Gender, growth and adaptation to climate change" in Powerful Synergies - Gender equality, economic development and environmental sutstainability. United Nations Development Programme (2013): 49-57

Lyon, Sarah, Josefina Aranda Bezaury, and Tad Mutersbaugh. "Gender equity in fairtradeorganic coffee producer organizations: Cases from Mesoamerica." Geoforum 41.1 (2010): 93-103.

Lyon, Sarah, Tad Mutersbaugh, and Holly Worthen. "The triple burden: the impact of time poverty on women's participation in coffee producer organizational governance in Mexico." Agriculture and Human Values 34.2 (2017): 317-331.

Maertens, Miet, and Johan FM Swinnen. "Gender and modern supply chains in developing countries." The Journal of Development Studies 48.10 (2012): 1412-1430.

Malapit, Hazel Jean L., and Agnes R. Quisumbing. "What dimensions of women's empowerment in agriculture matter for nutrition in Ghana?." Food Policy 52 (2015): 5463.

Malapit, Hazel J., et al. "Measuring progress toward empowerment: Women's empowerment in agriculture index: Baseline report." Intl Food Policy Research Institute (2014).

Malapit, Hazel Jean L., et al. "Women's empowerment mitigates the negative effects of low production diversity on maternal and child nutrition in Nepal." The Journal of Development Studies 51.8 (2015): 1097-1123. 
Meemken, Eva-Marie, Prakashan Chellattan Veettil, and Matin Qaim. "Toward Improving the Design of Sustainability Standards-A Gendered Analysis of Farmers' Preferences." World Development 99 (2017): 285-298.

Meemken, Eva-Marie, and Matin Qaim. "Can private food standards promote gender equality in the small farm sector?" Journal of Rural Studies 58 (2018): 39-51.

Melesse, Mequanint B., Adane Dabissa, and Erwin Bulte. "Joint Land Certification Programmes and Women's Empowerment: Evidence from Ethiopia." The Journal of Development Studies (2017): 1-19.

Peterman, Amber, et al. "Understanding the complexities surrounding gender differences in agricultural productivity in Nigeria and Uganda." Journal of Development Studies 47.10 (2011): 1482-1509

PGE-GCP. "A common measurement framework for gender equity in the coffee sector" (2017) https://www.globalcoffeeplatform.org/assets/files/02-CANS/GY/GCP-PGEGender-Common-Measurement-Framework-2017.pdf

Quisumbing, Agnes R., et al. "Gender, assets, and market-oriented agriculture: learning from high-value crop and livestock projects in Africa and Asia." Agriculture and human values 32.4 (2015): 705-725.

Raghunathan, Kalyani, Samyuktha Kannan, and Agnes R. Quisumbing. 'Women's selfhelp groups, decision-making, and improved agricultural practices in India." Agricultural and Applied Economics Association Annual Meeting, August 5-7, Washington, D.C. (2018)

Sekabira, Haruna, and Matin Qaim. "Can mobile phones improve gender equality and nutrition? Panel data evidence from farm households in Uganda." Food Policy 73 (2017): 95-103.

Tiruneh, Addis, et al. "Gender differentials in agricultural production and decisionmaking among smallholders in Ada, Lume, and Gimbichu Woredas of the Central Highlands of Ethiopia." International Maize and Wheat Improvement Center (CIMMYT), (2001).

United Nations Industrial Development Organization (UNIDO), "Guide on Gender Mainstreaming Agribusiness Development Projects." Vienna, (2015).

Uttaro, Robert P. "Diminishing choices: gender, small bags of fertilizer, and household food security decisions in Malawi." African Studies Quarterly 6.1 (2002): 2. 
World Bank. “Gender Equality and Development”. World Development Report. World Bank, 2012.

World Bank. "World Bank Group gender strategy (FY16-23): gender equality, poverty reduction and inclusive growth (English)". Washington, D.C. : World Bank Group (2015) http://documents.world bank.org/curated/en/820851467992505410/World-BankGroup-gender-strategy-FY16-23-gender-equality-poverty-reduction-and-inclusivegrowth

World Bank and IFPRI. "Gender and Governance in Rural Services: Insights from India, Ghana, and Ethiopia". World Bank, Washington, D.C., USA (2010).

Zhang, Quanda and Alberto Posso. "Microfinance and gender inequality: cross-country evidence" Applied Economics Letters, 24.20 (2017): 1494-1498 


\section{Annex}

\section{GII and HDI in ICO exporting Members}

\begin{tabular}{|c|c|c|}
\hline Country & GII & HDI \\
\hline Bolivia (Plurinational State of) & 0.454 & 0.681 \\
\hline Brazil & 0.413 & 0.757 \\
\hline Burundi & 0.474 & 0.418 \\
\hline Cameroon & 0.573 & 0.548 \\
\hline Central African Republic & $0.681^{*}$ & 0.357 \\
\hline Colombia & 0.389 & 0.742 \\
\hline Congo (Democratic Republic of the) & 0.655 & 0.444 \\
\hline Costa Rica & 0.303 & 0.788 \\
\hline Côte d'Ivoire & 0.666 & 0.478 \\
\hline Cuba & 0.303 & 0.788 \\
\hline Ecuador & 0.387 & 0.743 \\
\hline El Salvador & 0.395 & 0.674 \\
\hline Ethiopia & 0.509 & 0.451 \\
\hline Gabon & 0.542 & 0.694 \\
\hline Ghana & 0.550 & 0.585 \\
\hline Guatemala & 0.496 & 0.645 \\
\hline Honduras & 0.465 & 0.609 \\
\hline India & 0.534 & 0.627 \\
\hline Indonesia & 0.468 & 0.686 \\
\hline Kenya & 0.558 & 0.578 \\
\hline Liberia & 0.656 & 0.432 \\
\hline Madagascar & N/A & 0.514 \\
\hline Malawi & 0.623 & 0.470 \\
\hline Mexico & 0.348 & 0.767 \\
\hline Nepal & 0.488 & 0.566 \\
\hline Nicaragua & 0.465 & 0.652 \\
\hline Panama & 0.465 & 0.781 \\
\hline Papua New Guinea & 0.595 & 0.542 \\
\hline Paraguay & 0.466 & 0.702 \\
\hline Peru & 0.385 & 0.745 \\
\hline Philippines & 0.431 & 0.693 \\
\hline Rwanda & 0.389 & 0.51 \\
\hline Sierra Leone & 0.65 & 0.413 \\
\hline Tanzania (United Republic of) & 0.542 & 0.528 \\
\hline Thailand & 0.378 & 0.741 \\
\hline Timor-Leste & $\mathrm{N} / \mathrm{A}$ & 0.630 \\
\hline Togo & 0.572 & 0.495 \\
\hline Uganda & 0.528 & 0.505 \\
\hline Venezuela (Bolivarian Republic of) & 0.467 & 0.775 \\
\hline Viet Nam & 0.323 & 0.684 \\
\hline Yemen & 0.839 & 0.483 \\
\hline Zambia & 0.546 & 0.583 \\
\hline Zimbabwe & 0.540 & 0.529 \\
\hline
\end{tabular}

* GII data point for Central African Republic for year 2016

Source: UNDP 


\section{INTERNATIONAL COFFEE ORGANIZATION}

